\title{
Restoring fire-prone Inland Pacific landscapes: seven core principles
}

\author{
Paul F. Hessburg • Derek J. Churchill • Andrew J. Larson • Ryan D. Haugo • Carol Miller • \\ Thomas A. Spies $\cdot$ Malcolm P. North $\cdot$ Nicholas A. Povak $\cdot$ R. Travis Belote $\cdot$ Peter H. Singleton \\ William L. Gaines - Robert E. Keane - Gregory H. Aplet - Scott L. Stephens • Penelope Morgan • \\ Peter A. Bisson • Bruce E. Rieman • R. Brion Salter • Gordon H. Reeves
}

Received: 17 December 2014 / Accepted: 12 May 2015/Published online: 26 May 2015

(C) The Author(s) 2015. This article is published with open access at Springerlink.com

\begin{abstract}
Context More than a century of forest and fire management of Inland Pacific landscapes has transformed their successional and disturbance dynamics. Regional connectivity of many terrestrial and aquatic habitats is fragmented, flows of some ecological and physical processes have been altered in space and time, and the frequency, size and intensity of many disturbances that configure these habitats have been altered. Current efforts to address these impacts yield a small footprint in comparison to wildfires and insect
\end{abstract}

P. F. Hessburg $(\bowtie) \cdot$ N. A. Povak · P. H. Singleton · R. B. Salter

Pacific Northwest Research Station, USDA-Forest

Service, 1133 N. Western Ave., Wenatchee, WA 98801, USA

e-mail: phessburg@fs.fed.us

D. J. Churchill

College of the Environment, University of Washington,

Seattle, WA 98195, USA

\section{A. J. Larson}

College of Forestry and Conservation, University of

Montana, Missoula, MT 59812, USA

\section{R. D. Haugo}

The Nature Conservancy, 32 North 3rd Street, Suite 412, Yakima, WA 98901, USA

C. Miller

Aldo Leopold Wilderness Research Institute, Rocky

Mountain Research Station, USDA-Forest Service, 790

East Beckwith Ave., Missoula, MT 59801, USA outbreaks. Moreover, many current projects emphasize thinning and fuels reduction within individual forest stands, while overlooking large-scale habitat connectivity and disturbance flow issues.

Methods We provide a framework for landscape restoration, offering seven principles. We discuss their implication for management, and illustrate their application with examples.

Results Historical forests were spatially heterogeneous at multiple scales. Heterogeneity was the result of variability and interactions among native ecological

\section{T. A. Spies · G. H. Reeves}

Pacific Northwest Research Station, USDA-Forest

Service, 3200 Jefferson Way, Corvallis, OR 97331, USA

M. P. North

Pacific Southwest Research Station, USDA-Forest

Service, 1731 Research Park Drive, Davis, CA 95618, USA

R. T. Belote

The Wilderness Society, 503 West Mendenhall, Bozeman, MT 59715, USA

W. L. Gaines

Washington Conservation Science Institute, 12725 Wilson Street, Leavenworth, WA 98826, USA

R. E. Keane

Rocky Mountain Research Station, USDA-Forest Service, 5775 Highway 10 West, Missoula, MT 59808, USA 
patterns and processes, including successional and disturbance processes regulated by climatic and topographic drivers. Native flora and fauna were adapted to these conditions, which conferred a measure of resilience to variability in climate and recurrent contagious disturbances.

Conclusions To restore key characteristics of this resilience to current landscapes, planning and management are needed at ecoregion, local landscape, successional patch, and tree neighborhood scales. Restoration that works effectively across ownerships and allocations will require active thinking about landscapes as socio-ecological systems that provide services to people within the finite capacities of ecosystems. We focus attention on landscape-level prescriptions as foundational to restoration planning and execution.

Keywords Forest and rangeland restoration . Hierarchical organization - Large fires - Patch size distributions $\cdot$ Successional patches $\cdot$ Topographic controls

\section{Introduction}

Land management in the Inland Pacific United States (US) faces unprecedented challenges:

- A growing human population that demands contradictory or competing ecosystem services (Krieger 2001);

\section{G. H. Aplet}

The Wilderness Society, 1660 Wynkoop St., Suite 850, Denver, CO 80202, USA

\section{S. L. Stephens}

Department of Environmental Science, Policy, and Management, University of California, 30 Mulford Hall, Berkeley, CA 94720-3114, USA

\section{P. Morgan}

Department of Forest, Rangeland, and Fire Sciences, University of Idaho, 975 Perimeter Drive MS 1133, Moscow, ID 83844, USA

P. A. Bisson

Pacific Northwest Research Station, USDA-Forest

Service, 3625 93rd Ave., SW, Olympia, WA 98512, USA

B. E. Rieman

Seeley Lake, MT 59868, USA
- Impaired ability of some landscapes to provide these services due to past management (Millenium Ecosystem Assessment 2005);

- Increased exposure to large and often severe disturbances (Schoennagel et al. 2004; McKenzie et al. 2004; Agee and Skinner 2005; Hessburg et al. 2005; Peterson et al. 2005; Miller and Davis 2009; Miller et al. 2009; cf. Baker 2012; Williams and Baker 2012; Odion et al. 2014);

- New or alternative ecosystem states following large or severe disturbances (Allen et al. 2010; Odion et al. 2010);

- Decline and extinction of some native plant and animal populations, and increasing invasions by non-natives (Noss and Cooperrider 1994; Reed et al. 2003);

- High uncertainty regarding future effects of climate change (Millar et al. 2007);

- Diminished public confidence in land managers (Duncan et al. 2010; Keiter 2005; Williams and Jackson 2007).

To address these challenges, a new collaborative social contract for federal land management in the West is emerging ( Schultz et al. 2012; Butler 2013; Larson et al. 2013; Charnley et al. 2014). Established collaboratives seek to move past once crippling conflicts over natural resource management, forge social consensus around management approaches that can restore or create climate- and fire-resilient landscapes, and improve future options for people (Brown et al. 2004; Cheng and Sturtevant 2012; Charnley et al. 2014; Stephens et al. 2014). To effectively manage landscapes as resilient and adaptable social-ecological systems (Folke et al. 2005; Chapin et al. 2010), collaboratives must work from a solid scientific foundation.

In this review, we present principles from recent landscape science that are relevant to collaborative restoration, to raise the bar for land use planning and management across all ownerships. We emphasize Inland Pacific forests of Washington, Oregon, and California; however, our ideas are useful for landscapes beyond this domain, including the southwestern US and Rocky Mountain regions (Jain et al. 2008; Reynolds et al. 2013). Furthermore, we emphasize management of fire-prone forests, but recognize the importance of other physiognomic types as part of these landscapes, as well as lands intensively used by people. 
Recent research has expanded our understanding of multi-scale heterogeneity in historical fire-prone forests. Fire-prone forests are current or historical dry, mesic, or cold interior forest types that depend on wildfires for regeneration and succession. Heterogeneity resulted from interactions among climate, vegetation, topography, and disturbances that created successional patterns and shaped disturbance regimes to which native flora and fauna are adapted at fine-, meso-, and broad-scales. It evolved dynamically and conferred a measure of resilience to shifts in climate and recurrent contagious disturbances.

\section{Historical context-unintended consequences}

For most of the twentieth century, federal land management in the Inland Pacific emphasized wildfire suppression, domestic livestock grazing, and wood production to meet the demands of a growing society (White 1991; Langston 1995; Robbins 1999). Grounded in a utilitarian view of forests, silvicultural methods were devised to grow, harvest, and regenerate trees (Smith et al. 1997). Wildfires were viewed as threatening to people, infrastructure, and the timber supply.

Silviculture and forest management have focused on stands as the basic unit of organization (Puettman et al. 2012). Stands are defined as contiguous areas of trees with common structural, compositional, and biophysical conditions ( Helms 1988; Nyland 2002). Delineation of treatment units, 'operational stands'(sensu O'Hara and Nagel 2013), however, is shaped by added operational considerations including economic viability, road access, property boundaries, logging systems, and harvest scheduling.

These treatment units stood out in marked contrast to historical successional patches, which were variably-sized and shaped by the surrounding topography and prior disturbances. Even-aged management within operational stands promoted uniformity of tree conditions (e.g., size, density, species, spacing), while reducing costs of harvest, yarding, and log transportation. Uneven-aged management promoted variable size and age distributions, and often led to multistory structures dominated by shade tolerant species. Harvests of all types generally targeted high volume stands and removed large and old trees of fire tolerant species. Furthermore, prescriptions focused on tree conditions within stands and overlooked the larger scale patterns that emerged from this stand-based management.

Over time, timber harvest altered the size distributions, shapes and spatial arrangements of successional patches, while reducing numbers of large trees. Successional patches that had been historically created and maintained by disturbances (sensu Oliver and Larson 1996; O'Hara et al. 1996), often were fragmented by new patterns arising from stand management (Fig. 1; O'Hara and Nagel 2013). Resulting patterns varied by forest type and management. In cool, mesic mixed-conifer forests, where dispersed clear cuts were emphasized, successional patches were bisected by plantations, which were often smaller by two or three orders of magnitude (Franklin and Forman 1987; Belote and Aplet 2014; Hessburg et al. 1999b, 2000a). In marked contrast, in dry pine and mixed-conifer forests, elective removal of large, fire-tolerant trees and subsequent regeneration and release of shade-tolerant conifers increased the patch size and abundance of dense, multistory forest conditions (Hessburg et al. 1999b, 2000a, 2005; Keane et al. 2002, 2009; Hessburg and Agee 2003; Parsons and DeBenedetti 1979). Fire exclusion allowed these conditions to persist. In many areas, livestock grazing removed fine fuels and reduced fire frequency, further contributing to fire exclusion (Savage and Swetnam 1990; Belsky and Blumenthal 1997). Thus, the pattern observed in modern-day managed pine and mixedconifer landscapes is largely the result of stand management, roads, livestock grazing, and fire exclusion, which is now being altered by wildfires that often defy suppression efforts during extreme weather conditions (Schoennagel et al. 2004; Naficy et al. 2010; Lydersen et al. 2014).

Stand management and dispersed clearcutting necessitated development of extensive road networks to reach high-value stands (Reeves et al. 1995). The new roads altered local hydrology, increased chronic and catastrophic sedimentation, and reduced floodplain functioning via channelization (Luce and Black 1999; Jones et al. 2000). Roads fragmented aquatic habitats, and created fish passage barriers via crossings and culverts (Bisson et al. 2003; Rieman et al. 2003). Roads were effective fuelbreaks during moderate fire weather conditions; they played a role in spreading invasive plants, and provided access for firefighters (Forman 2003). Roads also disturbed wildlife nesting and denning, and interrupted breeding and dispersal 


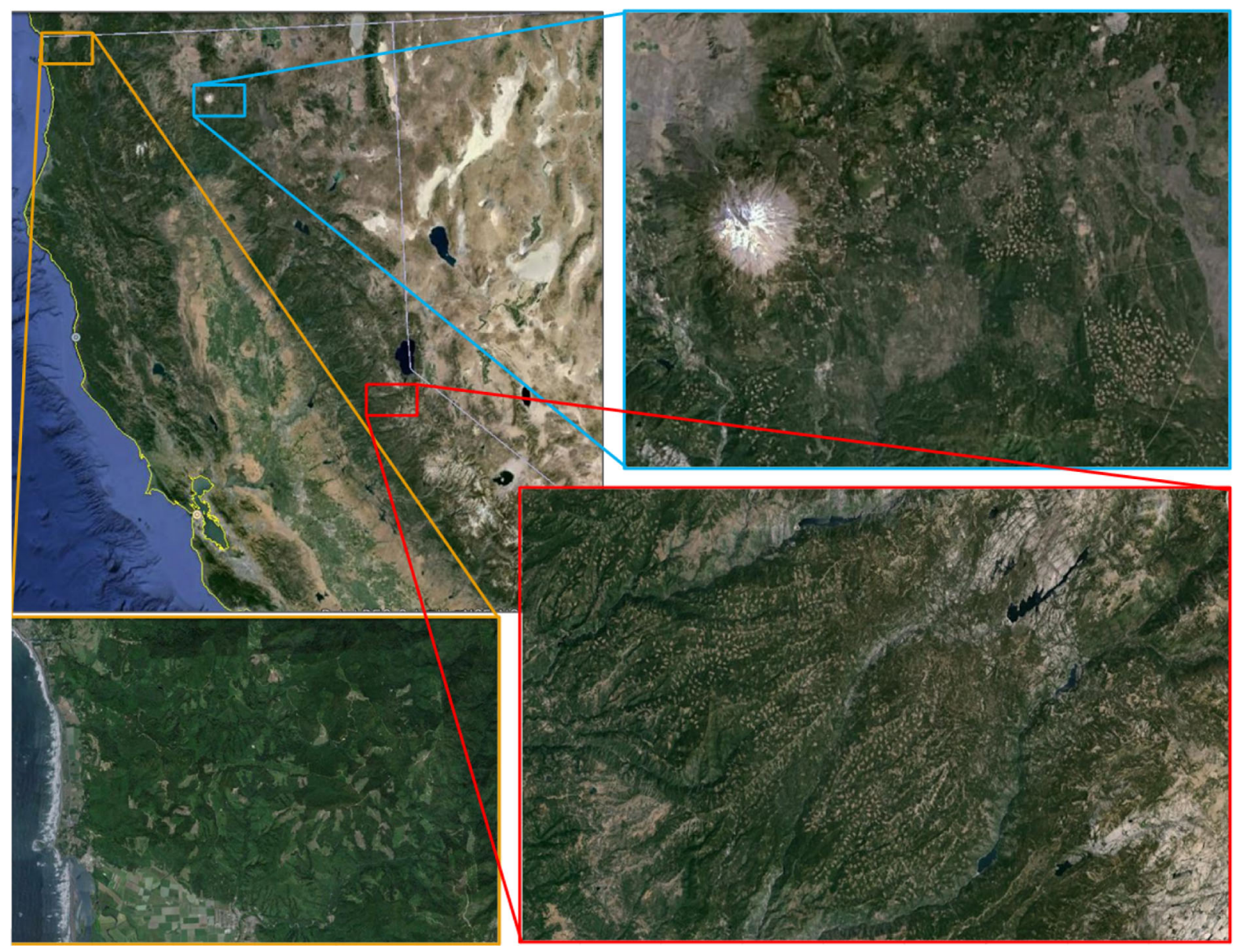

Fig. 1 Fragmentation of the northern California landscape (upper left). Shown in inset views are an area east of Mt. Shasta (upper right), an area along the northwest coast (lower left), and an area along the west slope of central Sierra Mountains (lower

habitat connectivity (Raphael et al. 2001; Gaines et al. 2003).

Today, successional patchworks of many forest landscapes no longer reflect a tightly linked relationship with their natural disturbance regime calling for restoration of many watersheds and lands (Keane et al. 2009; Wiens et al. 2012; Moritz et al. 2013). Instead, new fire, insect and pathogen disturbance regimes are driven by past management, a warming climate, and contagious patterns of fuels and hosts (Noss et al. 2006), fostering increased numbers of larger and more severe disturbances than occurred historically (McKenzie et al. 2004; Hessburg et al. 2005, 2013; Miller and Davis 2009). Predicted changes in the climate could exacerbate these trends (Millar et al. 2007; Allen et al. 2010; Stephens et al. 2013). right). Note the parcelization of the forest landscape by the emplacement of stand management units. All photos are courtesy of Google Earth 2014. Much of the area with recent clear cuts is on private lands

\section{Moving from stands to landscapes: core principles and management implications}

Re-purposing past approaches to forest management will not address the socio-political and ecological challenges that lie ahead (Lertzman and Fall 1998). Many ecologists, managers, and policy-makers are calling for restoration of many watersheds and landscapes (e.g., see Lertzman and Fall 1998; Bosworth 2006; Noss et al. 2006; ISAB 2011; Franklin and Johnson 2012; North 2012; North et al. 2012a; Franklin et al. 2014; Stephens et al. 2014). For example, the federal Forest Landscape Restoration Act of 2009 called for "collaborative, science-based ecosystem restoration of priority forest landscapes." Proposals for landscape-scale restoration have been 
Box 1 Seven core principles and their planning and management implications

Principle 1: Regional landscapes function as multi-level, cross-connected, patchwork hierarchies.

Implication: Conduct planning and management at appropriate scales to effectively restore multi-level landscape patterns, processes, and dynamics.

Principle 2: Topography provides a natural template for vegetation and disturbance patterns at local landscape, successional patch, and tree neighborhood scales.

Implication: Use topography to guide restoration of successional and habitat patchworks.

Principle 3: Disturbance and succession drive ecosystem change.

Implication: Move toward restoring natural fire regimes and the variation in successional patterns that supported them so that other processes may follow.

Principle 4: Predictable patch size distributions historically emerged from linked climate-disturbance-topography-vegetation interactions.

Implication: Move toward restoring size distributions of historical successional patches and allow changing climate and disturbance regimes to adapt them.

Principle 5: Successional patches are "landscapes within landscapes".

Implication: In dry pine, and dry to mesic mixed-conifer forests, restore characteristic tree clump and gap variation within patches.

Principle 6: Widely distributed large, old trees provide a critical backbone to dry pine and dry to mesic mixed-conifer forest landscapes.

Implication: Retain and expand on existing relict trees, old forests, and post-disturbance large snags and down logs in these types. Principle 7: Land ownership, allocation, management and access patterns disrupt landscape and ecosystem patterns.

Implication: Work collaboratively to develop restoration projects that effectively work across ownerships, allocations, and access needs.

developed from the Pacific Northwest to the northern Rockies, Sierra Nevada, and the Southwest. However, to be credible, these efforts will need an operational framework based on multi-scale planning and adaptive management, multi-partner and interdisciplinary collaboration, and core ecological principles that reach across scientific disciplines (Grumbine 1994).

Here, we focus attention on anunderutilized forest management concept: the landscape prescription. Scientifically grounded landscape prescriptions are needed to create habitat and successional patterns at local and regional landscape scales that move landscapes towards conditions that confer climate and disturbance resilience, while creating functional, wellconnected habitat networks for a broad array of native aquatic and terrestrial species. A landscape prescription can provide clearly articulated restoration objectives, target ranges for both total area (proportion of landscape) and patch size distributions of successional and habitat types, and specific guidance on how and where to adjust the spatial arrangement of patches (Perry et al. 2011; North et al. 2012b; Hessburg et al. 2013; Perera et al. 2004).

Resource managers and stakeholders need a common basis to identify long-term objectives for restorative landscape management. Here, we offer seven principles and we use them to construct a forwardlooking framework for management of fire-prone interior forest landscapes. We present these principles to help land managers and partners in the Inland Pacific move ahead with effective landscape restoration. The management implications we discuss for each principle can be applied in forest and project planning, designing treatments, monitoring, and collaborative learning (Box 1).

\section{Core principles}

\section{Principle 1}

Regional landscapes function as multi-level, crossconnected, patchwork hierarchies (O’Neill 1986; Urban et al. 1987; Wu and Loucks 1995), with patterns $^{1}$ and processes ${ }^{2}$ that interact across spatial scales(Holling 1992; Wu and David 2002; Peters et al. 2004; Falk et al. 2007).

\footnotetext{
${ }^{1}$ For example, successional or habitat conditions, surface and canopy fuels, tree mortality, fire severity patterns.

${ }^{2}$ For example, hydrologic and nutrient cycles, energy flows, and vegetation succession and disturbance dynamics.
} 

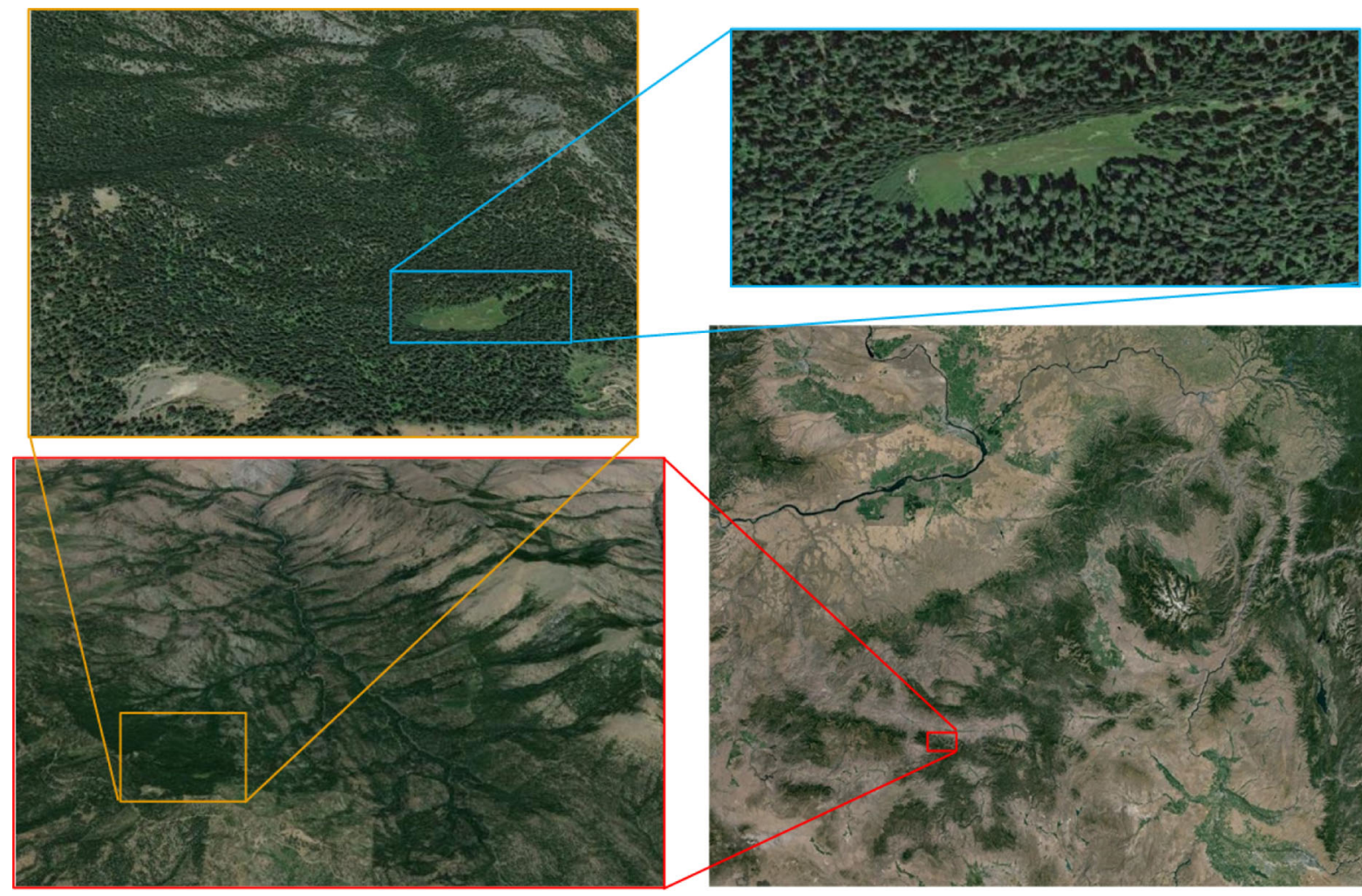

Fig. 2 Landscapes exist within landscapes and there are crossconnections between levels. Shown are the Blue Mountains of northeastern Oregon, USA (lower right); the Fields Creek watershed (lower left); a patch of headwaters' mixed-conifer forest (upper left) in upper Fields Creek, and an individual

We identify four levels of organization, but our framework can accommodate any number (Fig. 2). At the highest level, we identify ecoregions and ecosubregions (Fig. 3, 100,000's to 1,000,000's of ha; e.g., the Blue Mountains of eastern Oregon, or the Sierra Nevada Foothills of central California). Ecoregions are unique physiographic domains; their seasonal temperature, precipitation, and solar regimes, coupled with unique biotic assemblages, geology, and landforms, yield distinctive lifeform and successional patterns, and disturbance regimes (Küchler 1964; Hessburg et al. 2000b; Hargrove and Hoffman 2004). Ecoregional landscapes comprise local landscapes (Fig. 2, 10,000's to 100,000's of ha); groups of 10- or 12-digit hydrologic units [5th or 6th code watersheds and subwatersheds in the NHD watershed hierarchy (http://nhd.usgs.gov/)] may be used. As local landscapes, watersheds and groups of subwatersheds represent local environmental gradients and logical domains where terrestrial and aquatic ecosystem

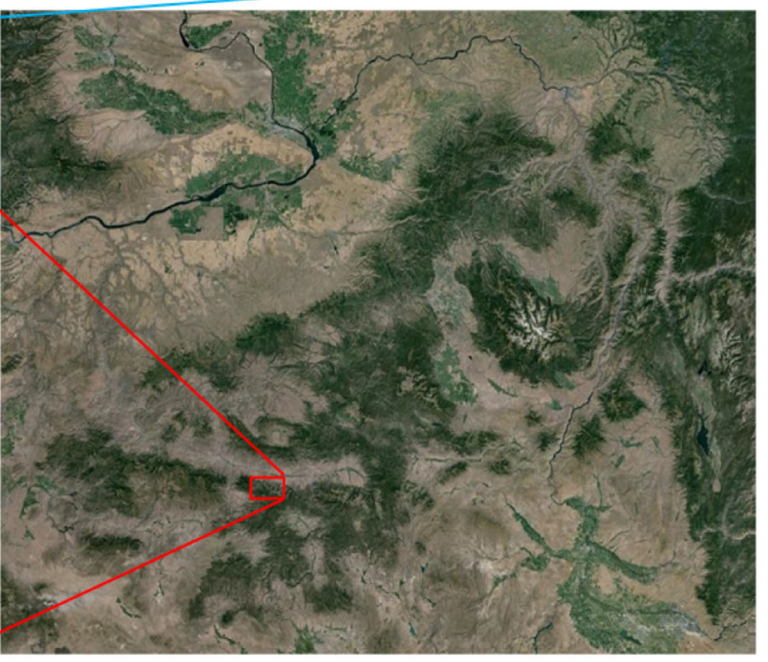

meadow patch embedded within the mixed conifer patch. Note that all levels exhibit pattern heterogeneity, which influences cross-scale species movements, habitat connectivity and permeability, and disturbance flows. All photos courtesy of Google Earth 2013

management issues may be simultaneously resolved. Local landscapes comprise successional patches, which may be small $(<1 \mathrm{ha})$ to large $(1000+\mathrm{ha})$ land areas, often strongly associated with topographic features, whose seral status is created by a dominant disturbance, and whose subsequent development depends on interactions among topographic and edaphic environments, stand dynamics processes, and subsequent disturbances. Tree neighborhoods comprise the lowest level of our hierarchy; these areas within successional patches have similar arrangements of individual trees, tree clumps and openings in similar micro-environments (Frelich and Reich 1999; Larson and Churchill 2012).In some dry pine forests, where fine grained disturbances are typical, tree neighborhood characteristics may override any obvious successional patchiness.

Over broad scales, historical successional patterns and disturbance dynamics reflected climatic variability and natural disturbance regimes of the 

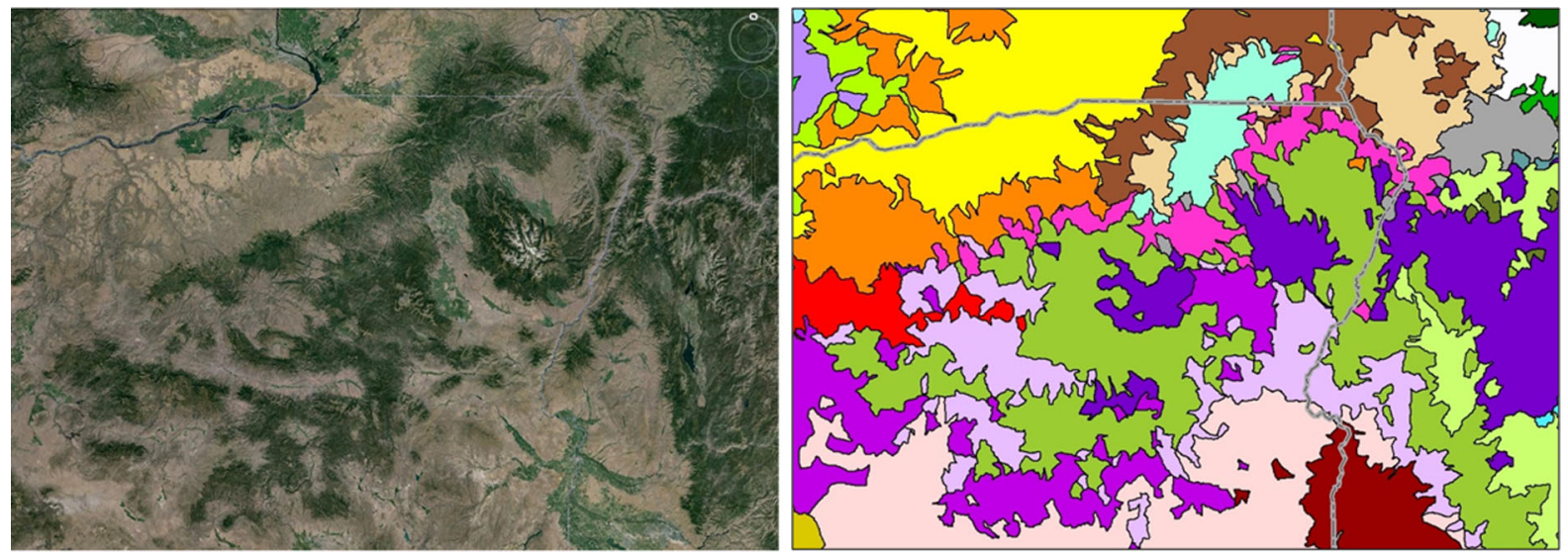

Fig. 3 Ecological subregions (ESRs, left) of the Blue Mountains province (right). Individual ESRs are unique areas that share a similar climate geology, geomorphic processes, biotic assemblages, and disturbance regimes. ESRs are taken from Hessburg et al. (2000b)

ecoregion (Whitlock and Bartlein 1997; Swetnam et al. 1999; Whitlock et al. 2003, 2010 Keane et al. 2009; Wiens et al. 2012). Within successional patches, tree clump and gap patterns, tree sizes (living and dead), and tree, shrub, and herb species compositions reflected fine-scale productivity, environmental, climatic, and disturbance controls (Larson and Churchill 2012; Churchill et al. 2013; Lydersen et al. 2013).

Hierarchical levels are connected through so-called "top-down" and "bottom-up" controls that operate within and across spatial scales (Wu and Loucks 1995; Wu and David 2002). In our suggested four-level hierarchy, spatial patterns and processes at the scale of the local landscape are partially constrained by the topdown control of climate, geology, landforms, and biota (Fig. 2; Urban et al. 1987; Turner 1989). Patchworks of local landscapes and those operating within successional patches and tree neighborhoods provide critical "bottomup" control of processes and patterns (Wu and Loucks 1995; Wu and David 2002). For example, patterns of tree species, tree sizes, and tree vigor at tree neighborhood, and successional patch levels can affect patterns of bark beetle induced mortality in local landscapes by influencing host contagion and beetle dispersal. However, these bottom-up controls can be overridden by the top-down influence of extreme climatic events that reduce host vigor or favor beetle survivorship (Bentz et al. 2010).

Implication

Conduct planning and management at appropriate scales to effectively restore multi-level landscape patterns, processes, and dynamics. A reasonable start is to put forest and woodland landscapes on a path to successional patterns and disturbance dynamics that reflect the natural disturbance regimes of regional and local landscapes (Swetnam et al. 1999; Keane et al. 2009; Wiens et al. 2012), and allow the future climate to adapt them. To place landscapes on this path, pattern modifications across scales will be needed in areas where past management alterations are greatest. Management to modify successional patterns should provide a good match to the disturbance ecology and expected future climatic regime of the landscapes in question.

Local landscape prescriptions are also needed that acknowledge constraints imposed by higher levels in the hierarchy that may limit what is achievable. For example, at the ecoregional level, shifting species ranges in response to warming may preclude the persistence of certain tree species at their trailing edge, while others may expand their ranges (Hampe and Petit 2005; Crookston et al. 2010). Thus, landscape prescriptions need to be compatible with the climate at the ecoregion and local landscape levels.

\section{Principle 2}

Topography provides a natural template for vegetation and disturbance patterns at local landscape, successional patch, and tree neighborhood scales. Topography modulates broad- to fine-scale patterns of climate and weather, surface lithologies and soils, geomorphic processes, vegetation productivity, and 
disturbances (Neilson 1986, 1995; Pearson and Dawson 2003). Thus, topography provides an intuitive and persistent physical template for vegetation patterns within regional and local landscapes.

The effect of this template is expressed most strongly in montane forests where ridges and valleys, benches, toe-slope environments, and north- and south-facing aspect patches shaped characteristic patterns and size distributions of historical successional patches (Lydersen and North 2012a; Fig. 4). For example, north-facing aspects and valley-bottoms historically supported many of the densest and most complex (multi-species, multi-aged and multi-layered) mixedconifer forest conditions (Camp et al. 1997, Olson and Agee 2005; Fig. 5). When fires occurred, these settings typically experienced more severe fire effects than south-facing aspects and ridges. In contrast, southfacing aspects and ridges displayed relatively low tree density, open canopy conditions, and burned more often and less severely (Agee 1993; Habeck 1994; North et al. 2009). Tree-killing bark beetles played a natural role in attacking fire-scarred, weakened, and low vigor ponderosa and Jeffrey pine, Douglas-fir, white fir and grand fir trees, and because of frequent fires, were generally endemic to the landscape. Likewise, defoliating insects frequented denser mixed-conifer patches, especially on north aspects and in valley bottoms (Hessburg et al. 1994).

\section{Implication}

Use topography to guide restoration of successional and habitat patchworks. Landscape prescriptions can use topography to tailor species composition, vegetation density, canopy layering, and other structural conditions to edaphic and environmental conditions (Lydersen and North 2012; Merschel et al. 2014). Partitioning the landscape into basic topographic settings, such as valley-bottoms, ridgetops, and southand north-facing slopes, can be an aid in distributing forest treatments to patch boundaries that are more logical than those based largely on proximity to roads (North et al. 2009, 2012b). Spatially mapped climatic water balance metrics (e.g., actual evapotranspiration and deficit) can be used to further refine and quantify topographic conditions into useful ranges for site potential and species composition determinations, and to guide climate adaptation (e.g., see Stephenson 1998; Dobrowski et al. 2011; Churchill et al. 2013;
Fig. 4 Map showing north and south-facing aspect patches, and ridge and valley bottom topographies in the vicinity of La Grande, Oregon. Topographic position is based on a $200-\mathrm{m}$ radius window. Aspect is displayed where the topographic position is neither valley bottom nor ridge top

Kane et al. 2015). Below, we provide a general approach for using topography in a landscape prescription using archetypal forest conditions as example landscapes.

Managing low- to mid-elevation south aspects and ridgelines. Southerly aspects and ridges can be managed to support fire-tolerant species in clumped tree distributions by: (1) favoring medium- (e.g., $40-60 \mathrm{~cm}$ dbh) to large-sized(e.g., 60-100 $\mathrm{cm}$ dbh, note that size ranges will depend on species and site productivity) trees; (2) promoting vegetation density and composition that is resilient to primarily low- and mixedseverity fires; and (3) maintaining relatively low vegetation density via forest thinning, prescribed burning, and/or managed wildfires. Tree size classes, tree clump and gap size distributions, and total canopy cover would vary from place to place and through time, but ranges of conditions could be calibrated from historical reconstructions (see Principle 5, Larson and Churchill 2012) and modified by incorporating expected climatic changes (e.g., see Churchill et al. 2013).

Managing low- to mid-elevation north aspects and valley-bottoms. North aspects and valley-bottoms generally support a mix of fire-tolerant and fire-intolerant tree species in relatively dense, often multi-layered arrangements. Because these fuel types typically support mixed surface and crown fire behavior, restorative prescriptions should allow patches of mixed and highseverity fires (see also Principle 4). These denser forests may also be subject to insect outbreaks. However, the naturally scattered distribution of north aspect and valley-bottom forests across the landscape (Fig. 4) typically constrains the frequency, severity, and duration of defoliator and bark beetle outbreaks by interrupting host contagion. Special attention to riparian zones is needed because such areas provide key structural elements of aquatic habitats such as large wood and undercut stream banks.

By suggesting topography as a natural template, we do not advise any strict correspondence of forest successional patches with topographic edges. Instead, applying feathered edges on the margins, for example, dry pine patches grading into dry or mesic mixed- 


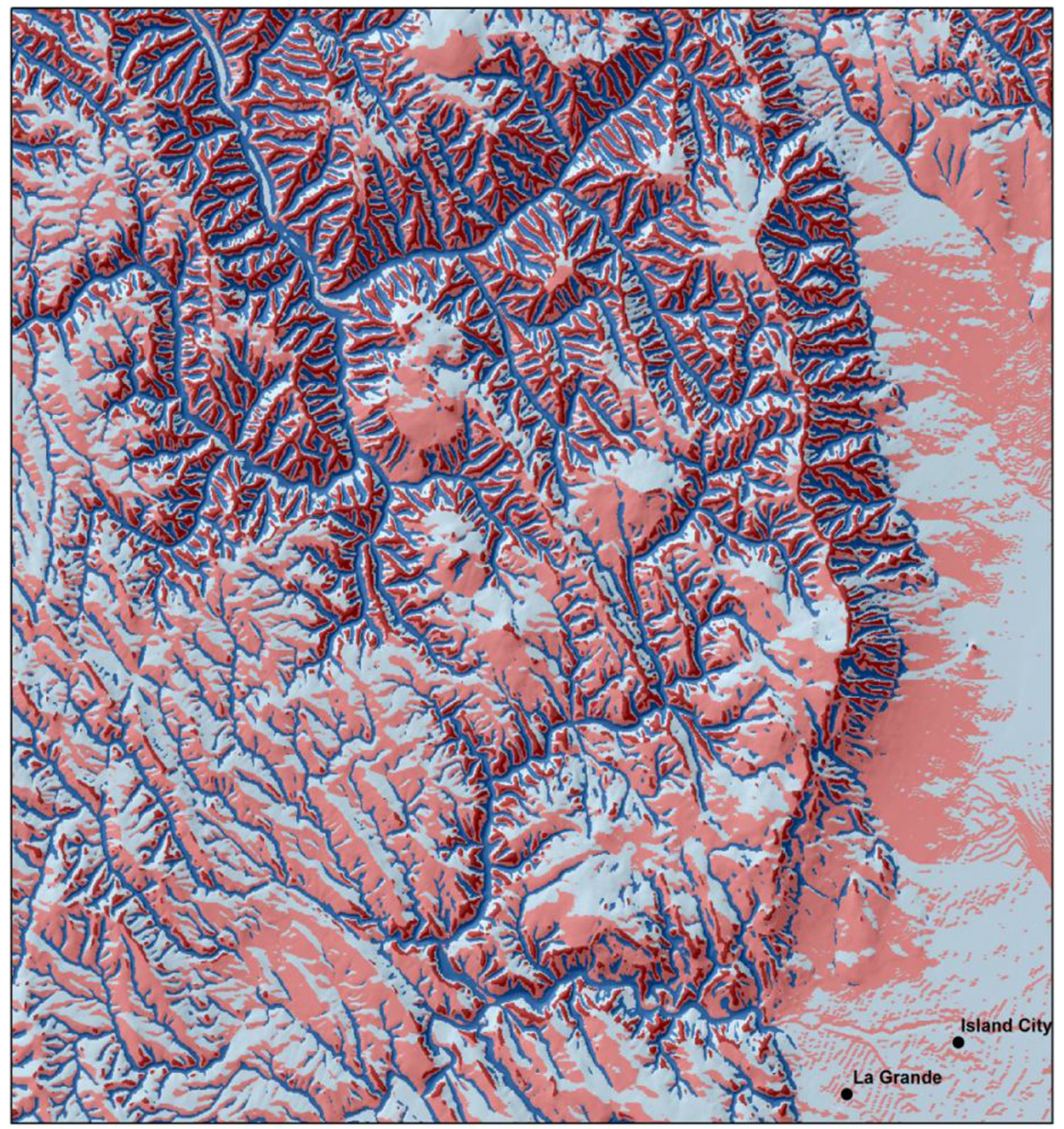

\section{Topographic position}

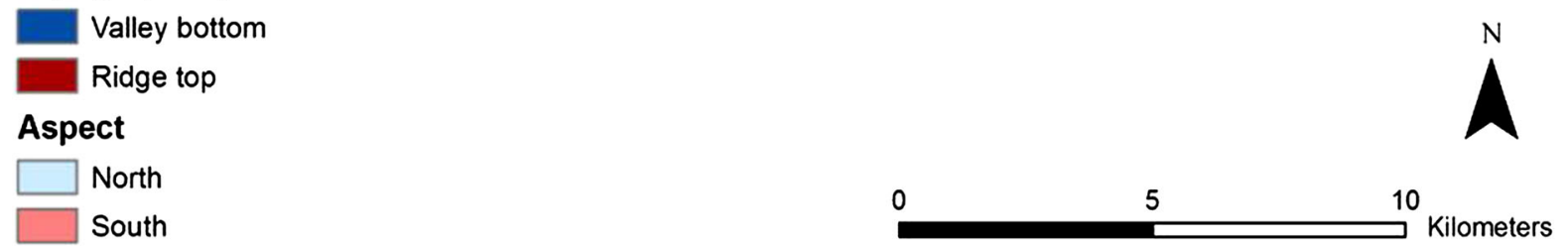

Topographic position is based on a $200 \mathrm{~m}$ radius window.

Aspect is displayed where the topographic position is neither valley bottom nor ridge-top. 

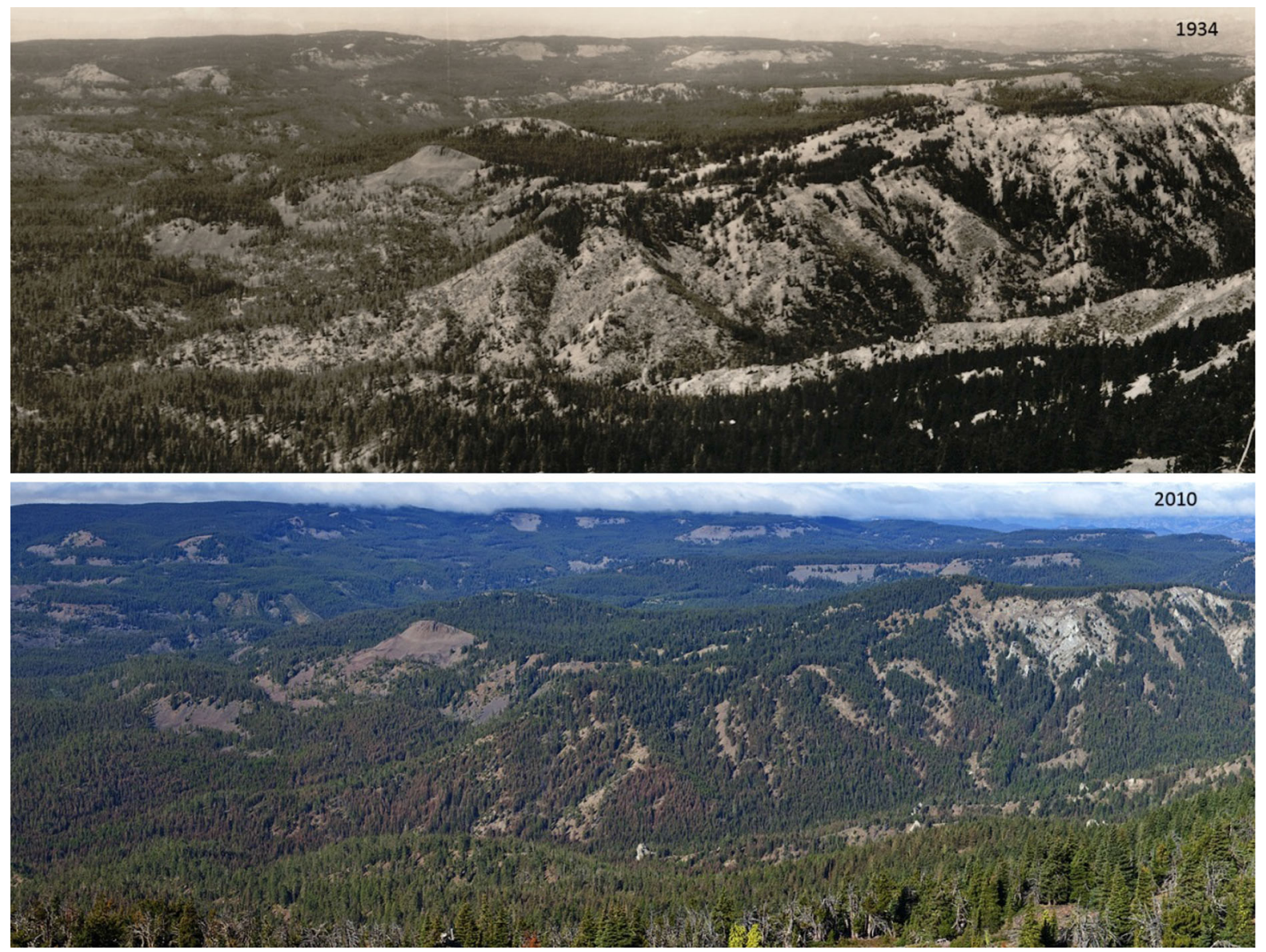

Fig. 5 Topography and physiography provided an intuitive natural template for life form, successional, and patch size patterns. This is the Mission Creek landscape just southwest of Wenatchee, in Washington State. Notice how aspect and topographic position influence wildfire and vegetation patterns: historically, south facing slopes and ridge tops display low tree density, early seral species, and open canopy vegetation

conifer patches(i.e., transitional zones with adjacent patches) might be more typical of the "soft edges" observed under more natural disturbance conditions (Stamps et al. 1987).

\section{Principle 3}

Disturbance and succession drive ecosystem change. Variability in climate, lifeform and successional patterns, and topographic and edaphic environments of a region (Fig. 6) determines disturbance regimes, which give rise to characteristic patterns of terrestrial and aquatic habitats (Bisson et al. 2009; Hessburg et al. 1999b; Keane et al. 2009; Merschel et al. 2014; Spies conditions resulting from frequent low and mixed severity fires, where surface fire effects dominated; north facing slopes and valley bottom were denser and exhibit more moderate site climate, and less frequent but more severe wildfire disturbances. The bottom photo was taken in 2010, and provided courtesy of John Marshall. The top photo was taken in 1934, and comes from the William Osborne collection (Arnst 1985)

et al. 2012; Wiens et al. 2012). In the West, fire was historically the dominant disturbance; insect, pathogen, and weather disturbances were subordinate but added important variability to lifeform and successional patterns. In contrast, today's patterns are largely a by product of the cumulative effects of human action and altered disturbance regimes. Insect outbreaks and wildfires now occur at larger scales, and both are being driven by a warmer climate (Littell et al. 2009, McKenzie et al. 2004; Bentz et al. 2010; cf. Baker 2012; Williams and Baker 2012; Odion et al. 2014). Consequently, large and severe bark beetle outbreaks and wildfires are more rapidly driving landscape change today compared with the past. High-intensity wildfire 


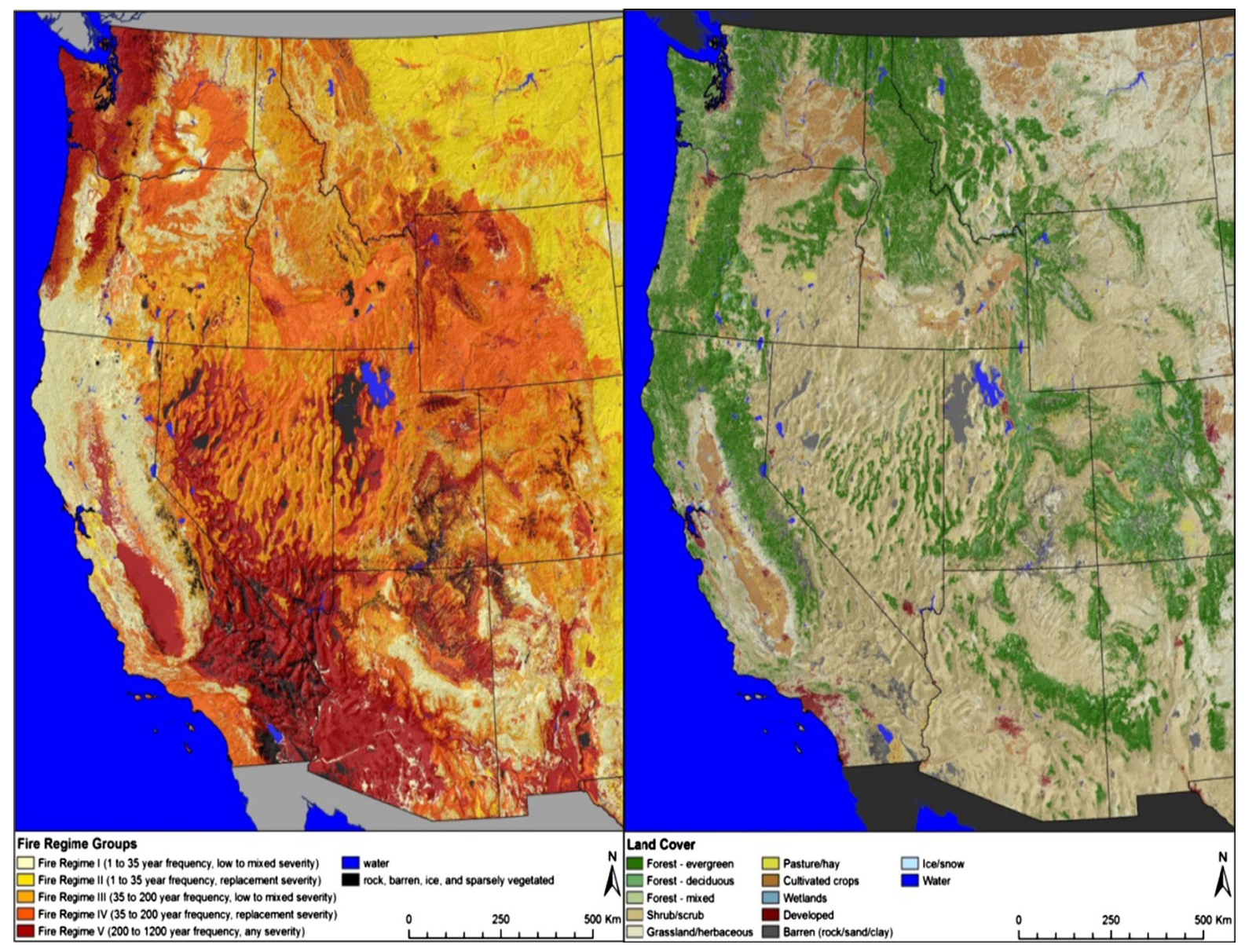

Fig. 6 Historical fire regime groups of the western United States (left). Note the relationship of fire regime zones to broad topographic gradients and land surface forms. Data are from www.landfire.gov. Land cover types are shown in the map to the right. Notice the high degree of correspondence between the fire

events and insect outbreaks can rapidly change ecoregional landscape structure and impact large areas, especially in comparison to the area currently influenced by restorative treatments (e.g., see Fig. 7).

\section{Implication}

Move toward restoring natural fire regimes and the variation in successional patterns that supported them so that other processes may follow. Planning and management should identify and restore natural disturbance regimes ${ }^{3}$ to create resilient landscapes. In

\footnotetext{
3 The fire regime includes the frequency, severity (effects), intensity (energy release), size distribution, and seasonality of
}

regime and land cover maps. Both maps are shown with a 200-m resolution hill-shade with z-augmentation. Data are from the 2006 National Land Cover Dataset (http://www.mrlc.gov/ nlcd2006.php)

some wilderness and roadless areas, the management of natural fire regimes appears to have restored successional patterns and resilient landscapes (Collins et al. 2009, Parks et al. 2015). In other places, creating landscapes where successional patterns, disturbances, and climate dynamics are more in sync will require modification of forest structure and composition patterns. This is especially true of dry to mesic mixed-coniferous forests that are currently most

Footnote 3 continued

fires. The natural fire regime is that which generally occurs when variation in fire frequency, severity, seasonality, and extent reflects characteristic interactions between the biota, geology, and climate settings of the forest type and ecoregion (Swetnam et al. 1999; Landres et al. 1999). 

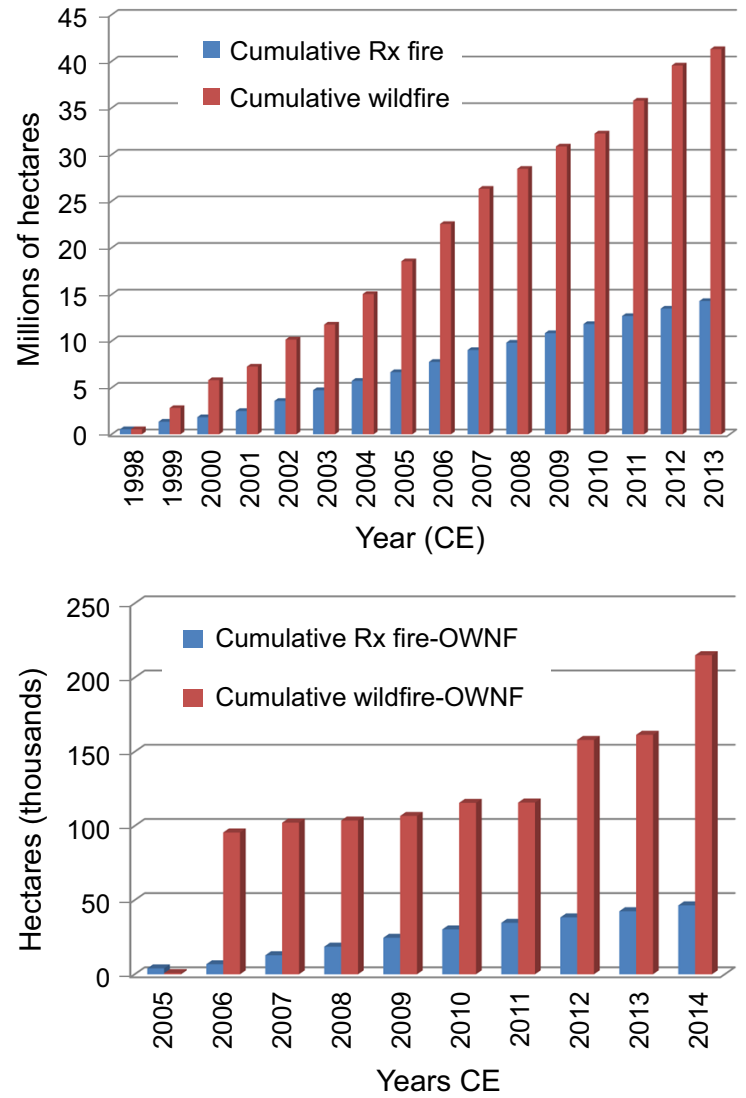

Fig. 7 (Top) area burned (millions of hectares) by cumulative prescribed (Rx) versus wildfires, from 1998 to 2013, on all State and federal agency lands throughout the US. Data are available at: http://www.nifc.gov/fireInfo/fireInfo_statistics.html. Note that the ratio of wild to $\mathrm{Rx}$ burned ha is $\sim 3: 1$. (Bottom) area burned (thousands of hectares) by cumulative prescribed ( $\mathrm{Rx})$ versus wildfires, from 2005 to 2014, on the Okanogan-Wenatchee National Forest (OWNF), eastern Washington. The ratio of wild to Rx burned ha on the OWNF is $\sim 5: 1$

departed from historical fire regime conditions (Agee 1998). Naturally occurring (e.g., wildfires) and wellplanned human-caused disturbances (mechanical and/ or prescribed burning treatments) can be used to modify successional patterns so they better match the disturbance ecology of the landscapes in question (see Box 2). Management activities should avoid the development of additional permanent roads. Rather, efforts should work within existing or reduced road networks, staying away from especially sensitive areas (Rieman et al. 2000, 2010).

The historical range of variability (HRV, Keane et al. 2009; Landres et al. 1999; McGarigal and Romme 2012; Wiens et al. 2012) of regional successional patterns can be used to inform management targets, where these reference conditions are based on climates that are similar to those anticipated in the future (Stephens et al. 2008, 2010). Moreover, the climatic variability during the HRV reference period undoubtedly overlaps with future climates, making them a useful reference. However, where HRV reference conditions are based on climates that highly differ from those anticipated in the future, they will be far less useful.

Several authors have referred to a future range of variation (FRV), which identifies alternative reference conditions that are suited to a predicted future climate (Hessburg et al. 2013; Keane et al. 2009; Moritz et al. 2011, 2013). In ecoregions where the anticipated twenty first century climate is much warmer and drier/ wetter than that of the early twentieth century, FRV reference conditions will be most useful to guide restoration efforts (USFS 2012; Hessburg et al. 2013). The FRV in some ecoregions is currently being approximated using either historical or contemporary analogue landscapes with successional patterns that have experienced the predicted future climate (Hessburg et al. 2013) or via succession and disturbance simulation modeling techniques (Keane et al. 2002; Loehman et al. 2011; Miller 2007). Both techniques are useful for exploring alternative vegetation patterns that will be fostered by a changing climate and understanding desirable changes to the existing conditions.

In some cases, the restoration approach will need to recognize current vulnerabilities to uncharacteristic disturbances and landscape inertia associated with other ecological processes (Merschel et al. 2014; Stephens et al. 2008, 2010; Stine et al. 2014). For example, in eastern Oregon, Douglas-fir and grand fir regeneration has become so widespread during the period of fire exclusion that seed rain from these species makes it unlikely that ponderosa pine will reestablish as a dominant species even after fires (Merschel et al. 2014). Re-establishment of pine may necessitate extensive cover type manipulation (Stine et al. 2014).

Restoration of resilient landscapes will not be feasible everywhere and some landscape prescriptions will need to acknowledge that long-term, unavoidable shifts in landscapes toward novel or "hybrid" ecosystems have occurred (Hobbs et al. 2009). In the future, western forests will contain more people, non-native 
Box 2 A greatly enlarged role for managed surface and crown fires

Conventional restoration activities take place at the stand-scale, but such activities will not likely scale up to accomplish needed
ecoregional and local landscape pattern modification. Furthermore, conventional vegetation management practices alone will not
restore fire regimes or mimic fire effects. Most of the work of restoring landscapes will likely need to be done using managed
wildfires over large areas and prescribed burning (North et al. 2012a, 2015), with mechanical treatments in key areas that require
spatial precision of outcomes and existing road access. This increased tolerance for wildfire, especially during moderate fire years
and shoulder seasons, will require continued public education on the ecological role of fire, as well as changes in policies and
professional incentives for forest managers. Cutting trees, whether commercially or pre-commercially, can emulate fire effects on
tree density and layering, but it cannot reproduce the effects of fire on nutrient cycling, snag creation, surface fuel reduction,
mineral seedbed preparation, and regenerating associated shrub and herb vegetation (Johnson 1992, Johnson and Miyanishi 1995).
If not designed with clear ecological objectives and constraints, commercial timber harvest can result in removal of scarce large-
sized trees to cover harvesting costs, reduced snag densities, excessive soil compaction, simplification of spatial patterns, and
residual fine fuel buildup that can promote future fire spread. This is a particular concern adjacent to riverine systems, where
retention of large dead wood is critical. In contrast, management ignited or managed wildfires burning under moderate fire weather
conditions can often accomplish ecological objectives without timber harvest, as has been observed in some wilderness and road
less areas, and in forests where mixed and high-severity fires naturally dominate (Meyer 2015).

species, an altered climate, and increased demands for carbon storage, food and water, minerals, wood and other forest products. Some long-term shifts will preclude a return to pre-development conditions (Higgs et al. 2014). Planning for sustainability will require the best efforts of resource economists and physical, biological, and social scientists.

\section{Principle 4}

Predictable patch size distributions historically emerged from linked climate-disturbance-topographyvegetation interactions. Low, mixed, and high severity ${ }^{4}$ wildfires historically maintained heterogeneous patchworks of burned and recovering vegetation in a fairly predictable variety of successional states and patch sizes (the HRV), with insect, pathogen, and weather disturbances adding to pattern complexity (Agee 1993, 1998). Historically, landscapes were patchworks of small $\left(10^{1}\right.$ to $10^{2}$ ha) to large $\left(10^{3}\right.$ to $\left.10^{4} \mathrm{ha}\right)$ patches with dead trees, early seral grasslands and shrublands (pre-forest conditions, Swanson et al. 2010), bare ground, and patches of new forest (Fig. 8; Moritz et al. 2011; Perry et al. 2011). For example, in the Blue Mountains and Northern Cascades provinces, as much as a third of the total area that was capable of producing dry, mesic, or cold forests

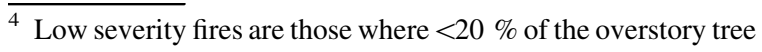
cover or basal area is killed by fire and fires are generally surface fires. Mixed severity fires are those where $20-70 \%$ of the overstory tree cover or basal area is killed by fire, and fires typically display a mix of surface and crown fire. High severity fires are those where $>70 \%$ of the overstory tree cover or basal area is killed by fire, and fires are primarily crown fires (Agee 1993).
}

was in either pre-forest or early seral condition (Hessburg et al. 1999a, b, 2015). The resulting patchwork of successional and environmental conditions resisted abrupt and widespread changes at local and regional landscape scales by reducing fuel contagion and the likelihood of large and severe fires (Collins et al. 2009, Hessburg et al. 1999b; Keane et al. 2009; Malamud et al. 1998; Moritz et al. 2013; Peterson 2002; Stephens et al. 2015). Large wildfires and insect outbreaks (e.g., Miller and Keen 1960) occurred when extreme climate and weather conditions overrode the spatial controls that successional and fuel patterns, and topography provided (Littell et al. 2009; McKenzie et al. 2004; Westerling et al. 2006), but even large fires resulted in patchy successional landscapes (Cansler and McKenzie 2014).

Low, mixed, and high severity fires and resulting successional patches occurred in predictable size distributions, like those shown in Fig. 9. (Hessburg et al. 2007; Moritz et al. 2011; Perry et al. 2011). At any one time, most patches (80-95\%) were relatively small, 1's to 100's of ha, and accounted for a minority of the disturbed area (Malamud et al. 1998; Moritz et al. 2011). The remaining patches were medium- to large-sized, 1000's to 10,000's of ha, and occasionally very large, 100,000's of ha, and together these constituted the majority of area disturbed by fire (Malamud et al. 1998, 2005, Moritz et al. 2011; Perry et al. 2011). The size distribution of disturbance events and the resultant successional patch mosaic approximated a truncated power-law model (Moritz et al. 2011; Perry et al. 2011); a feature that is suspected to have held across disparate ecoregions, despite large variability in biogeoclimatic conditions. Such patterns are also found in the size distribution of 

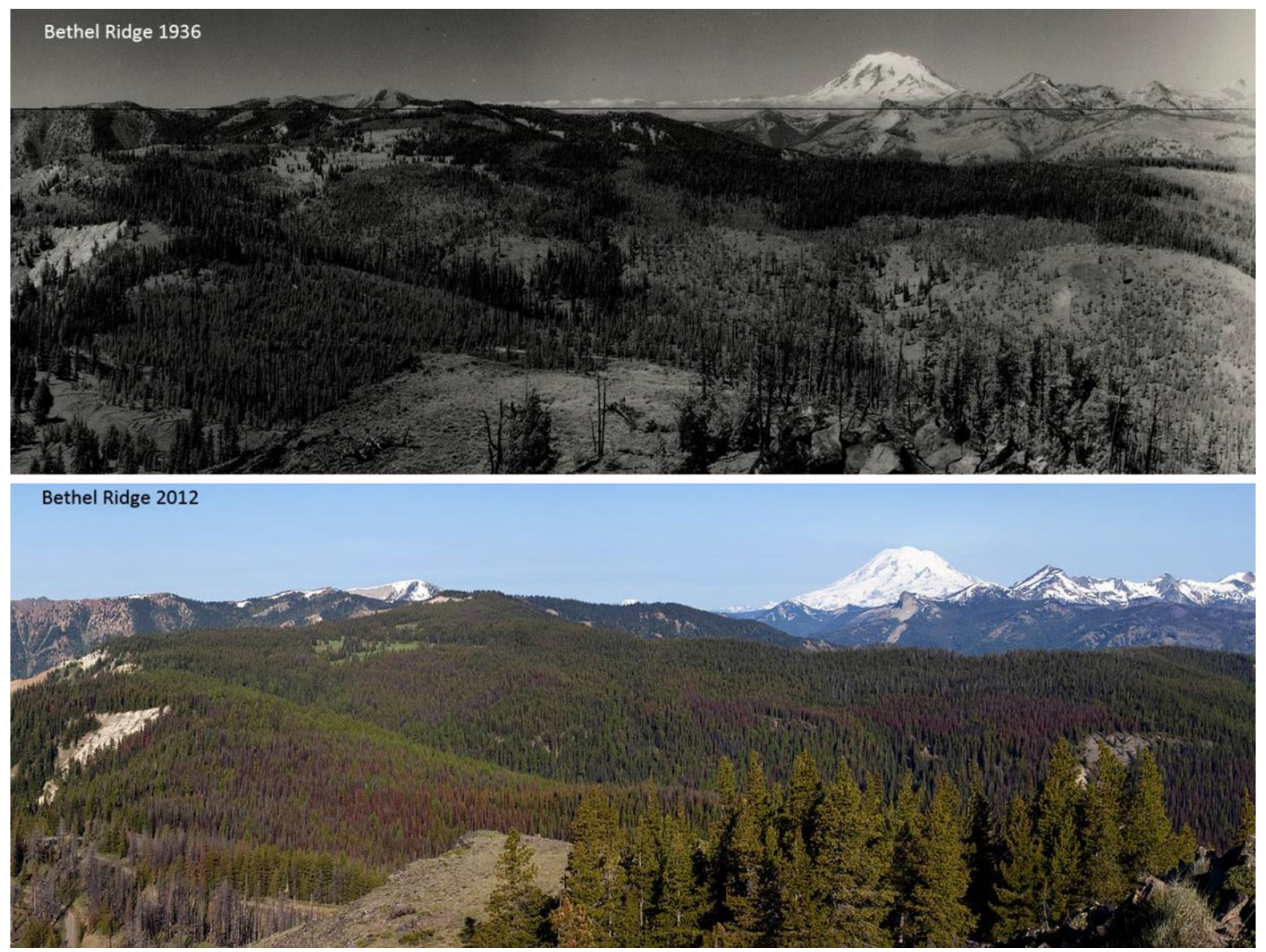

Fig. 8 Large areas of recently burned and recovering forest were commonplace in early twentieth-century forests of the inland Pacific West. This is the Bethel Ridge landscape in eastern Washington State, which is located east of Mt. Rainier and north of Rimrock Lake. Notice in the top photograph recently burned areas in the background that are in a pre-forest condition, while patches with seedlings, saplings, and pole sized trees are evident in mid- and foreground areas. In the bottom

certain topographic features (e.g., north-south aspect patches), which may indicate topographic control as a partial mechanism for ecosystem resilience to recurrent disturbances (Moritz et al. 2011; Box 3).

\section{Implication}

Move toward restoring size distributions of historical successional patches and allow changing climate and disturbance regimes to adapt them. Historical successional patch size distributions were the by product of photo, it is evident that fires have been largely excluded since the top photo was taken, and the forest appears to be continuous with little variation in age, density or size. Notice too that many of the areas that were recently burned in the top photo show clear evidence of bark beetle mortality (brown patches) in the bottom photo. The bottom photo was taken in 2012 by John Marshall. The top photo was taken in 1936, and comes from the William Osborne collection (Arnst 1985)

ongoing disturbances and changes to the climate system, providing a broad landscape resilience mechanism. If successional pattern conditions today were those of pre-management era forests, we would have minimal concern for their capacity to adjust to the climatic changes we are experiencing today.

Successional patches include non-forested "openings", the largest of which may still be evident today, though their margins have been encroached upon (Arno and Gruell 1986; Coop and Givnish 2007). Smaller openings have disappeared (Skinner 1995), and their historical distribution can be determined 

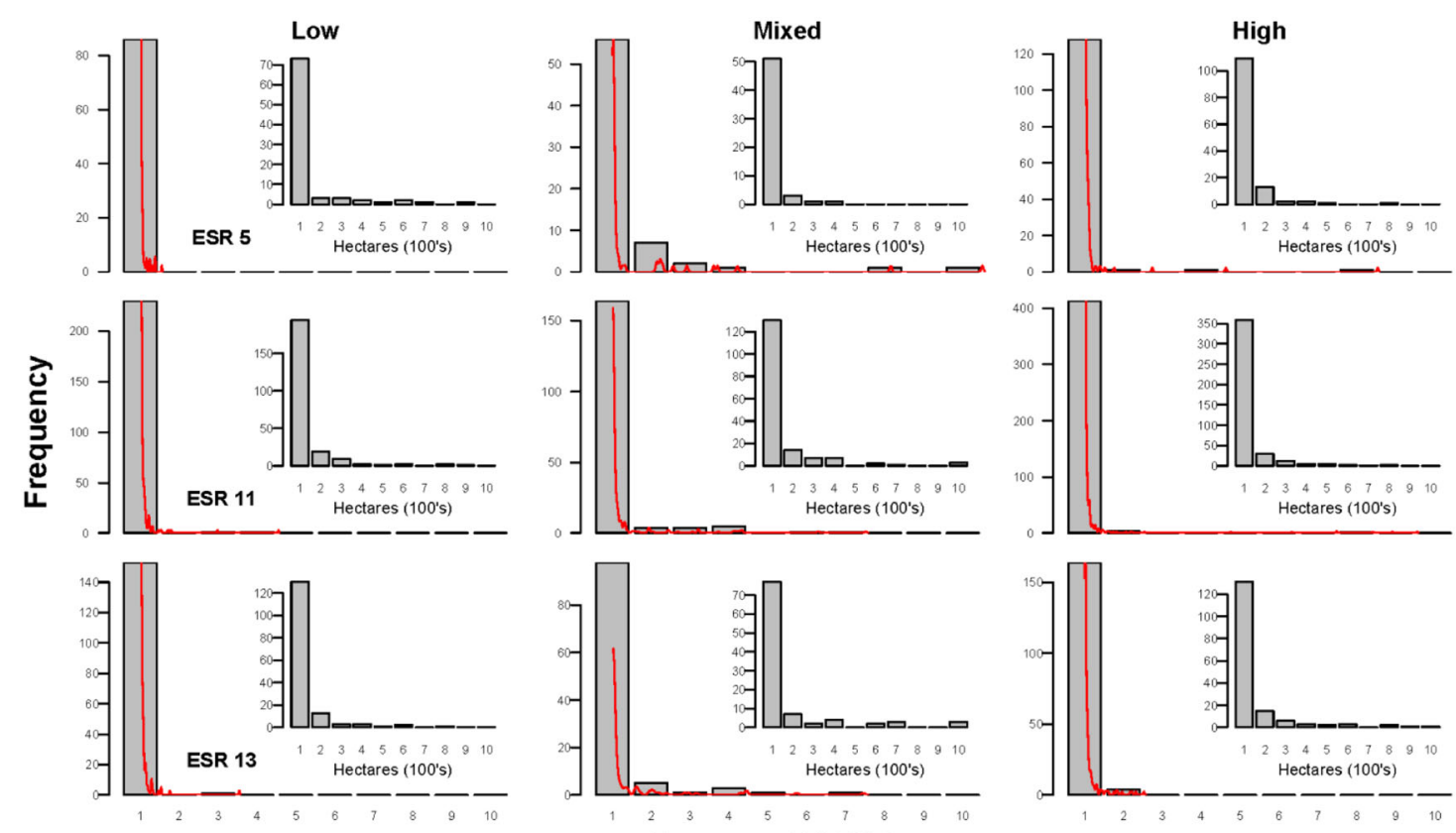

Hectares (1000's)
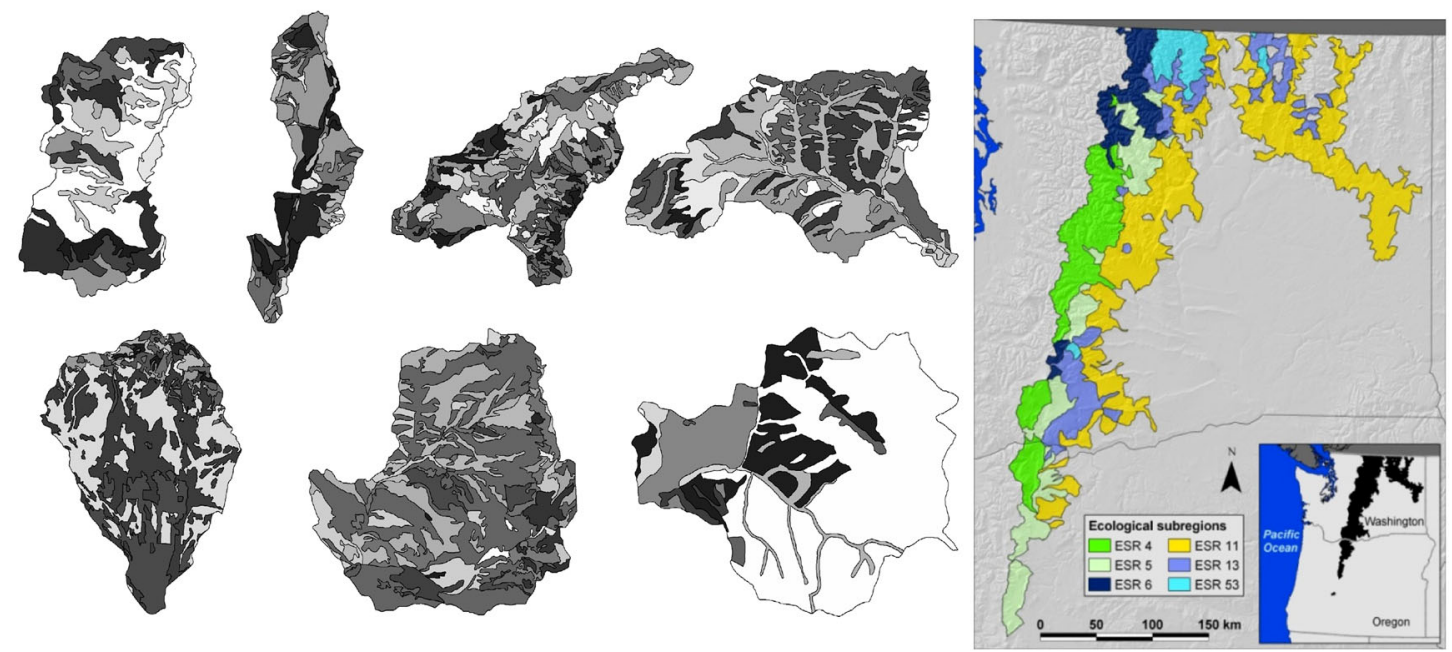

Fig. 9 Shown are maps of six ecological subregions (ESRs) in eastern Washington (lower right, Hessburg et al. 2000b), reconstructed historical fire severity patch size distributions within three of them (upper, ESRs 5, 11, and 13 (Perry et al.

from reconstructions of fine-scale forest structure (Principle 5). In the absence of local, historically derived information, landscape prescriptions should focus on increasing the frequency of variably-sized openings and successional patches (Dickinson 2014).

Patch size distributions will fluctuate as they adjust to climate, and to the proportion of the area affected by
2011; Hessburg et al. 2007), and example variability in historical successional patch sizes and arrangements (lower left, adapted from Perry et al. 2011) within ESR 13

wild and managed fires and vegetation treatments (Keane et al. 2002). However, as patch size distributions of successional patches become more in sync with current climate and natural disturbance regimes, we expect that these adjustments will become less dramatic and abrupt, and offer less uncertainty to future habitat conditions. 
Box 3 "Perfect storm" conditions for large wildfires

Dynamic interactions among the climate, disturbances, successional conditions and patterns of environments were the mechanism by
which successional mosaics historically emerged in dry, mesic, and cold forests of the inland Pacific West. Mosaics varied across
space and time, but variability was constrained by the dominant climate and disturbance influences. In contrast, today's
successional patterns, fueled by a warming climate, appear to be driving more severe disturbance regimes (generally lower fire
frequency and higher severity) in a kind of 'perfect storm', with uncertain ecological trajectories associated with some fires
(Lydersen et al. 2014). By excluding all but the largest fires via suppression, we enable successional processes to create dense
patches of stressed trees on some parts of the landscape, with higher than historical surface fuel loads, high landscape contagion,
and dense canopy fuels. This successional landscape is a regional-scale condition in which wildfires are more likely to be large and
often severe. Moreover, it is marked by vast areas of shade-tolerant, fire sensitive species (e.g., grand, white fir, Douglas-fir,
subalpine fir, Engelmann spruce), that produce abundant seeds, and that can colonize disturbed areas, further reinforcing a broad-
scale species compositional shift.

\section{Principle 5}

Successional patches are "landscapes within landscapes". Even though patches themselves define the heterogeneity of local landscapes, they too are defined by within-patch heterogeneity. Reconstructions from pre-settlement era and contemporary forests with active wildfire regimes (Fry et al. 2014; Larson and Churchill 2012; Lydersen et al. 2013; Fig. 10) show that patches in fire-prone dry and mesic mixed-conifer forests comprised fine-scale mosaics of individual trees, and tree clumps and openings (gaps) of various sizes. These spatial patterns influence patch-level resilience to disturbances, rates of succession and stand dynamics processes (Sánchez Meador et al. 2009; Stephens et al. 2008; Dodson et al. 2008; Fettig et al. 2007), and wildlife habitat characteristics (Kotliar and Wiens 1990; Dodd et al. 2006; Wiens and Milne 1989).

\section{Implication}

In dry pine, and dry to mesic mixed-conifer forests, restore characteristic tree clump and gap variation within patches. Patch level prescriptions should aim to restore variable patterns within stands and begin to dissolve the uniformity achieved in prior stand-level prescriptions (Churchill et al. 2013; Franklin et al. 2013; Reynolds et al. 2013; Jain et al. 2008; North et al. 2009); especially in even-aged stands. Presettlement era and contemporary forests with active wildfire regimes (e.g., Fulè et al. 2012; Harrod et al. 1999; Larson and Churchill 2012; Lydersen et al. 2013; Fig. 10) provide a reference for these conditions. In many cases, old stand and plantation boundaries can be dissolved to create large patches that better match the topographic template across a broad range of patch sizes (see Principle 2 above) (North et al. 2009; Box 4).

\section{Principle 6}

Widely distributed large, old trees provide a critical backbone to dry pine and dry to mesic mixed-conifer forest landscapes (sensu Ellison et al. 2005; Hunter 2005). Large trees dominated the overstories of open and closed canopy, old forest patches, and they were more common across a much broader area as a remnant of former overstories after mixed and high severity disturbance (Lutz et al. 2009; Collins et al. 2011; Hagmann et al. 2013, 2014; Table 1). Whether as old forest or remnant trees, many of these large, old trees were resistant to wildfires (Fig. 11), surviving extended droughts, providing seed and genetic resources spanning centuries, and contributing important snag and cavity habitat after they died. Early seral species such as ponderosa, Jeffrey and sugar pines, Douglas-fir, and western larch were the primary old tree species in locations with more fire and drought stress. Old trees of fire intolerant species (e.g. grand and white fir, western red cedar, Engelmann spruce (Picea engelmannii Parry ex Engelm.), and an assortment of poplars (Populus spp., Marshall 1928) were more common as fire frequency decreased, and in microsites with springs, seeps, or hyporheic exchange. Patches of closed canopy, old forests were generally found in refugial settings such as north aspects, in valley-bottoms along tributary streams and creeks near a major confluence, in middle or upper headwall settings, in highly-dissected topography, and in locations that experienced less frequent wildfires by virtue 

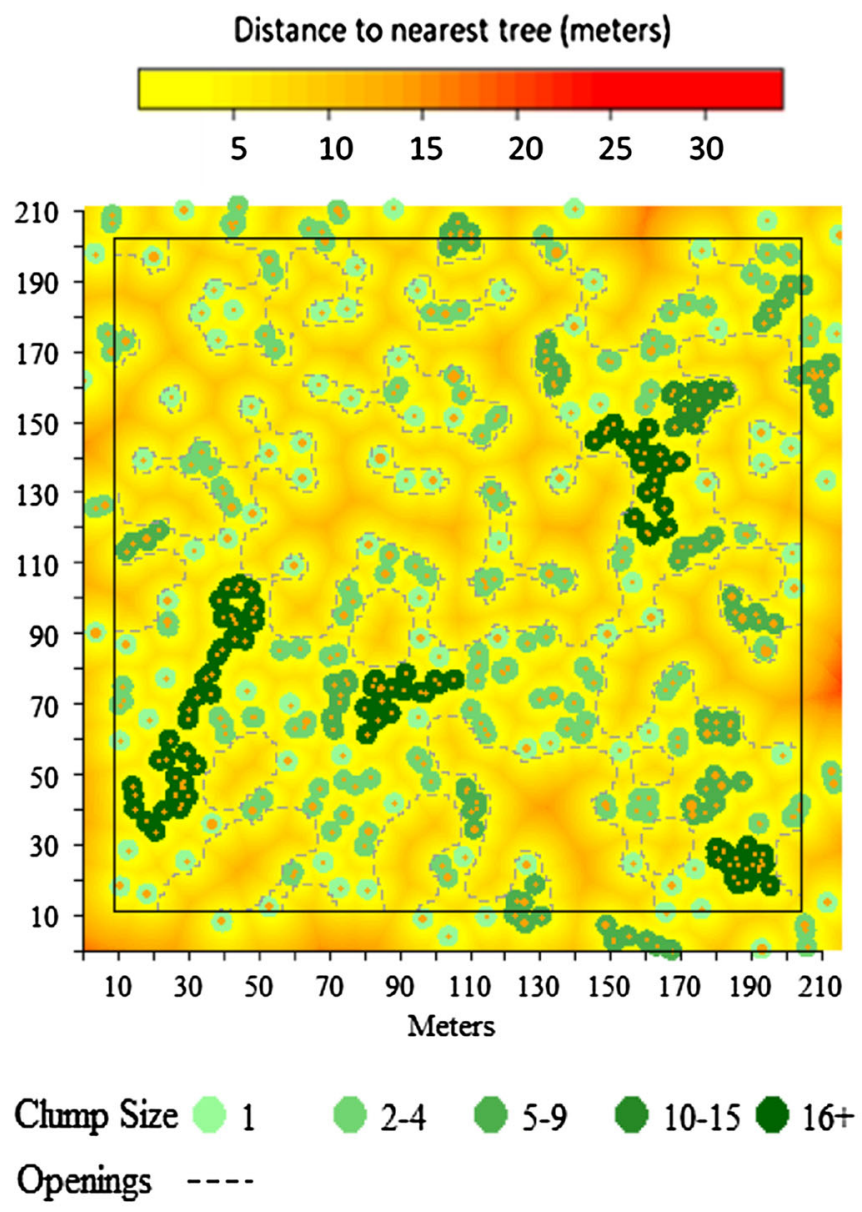
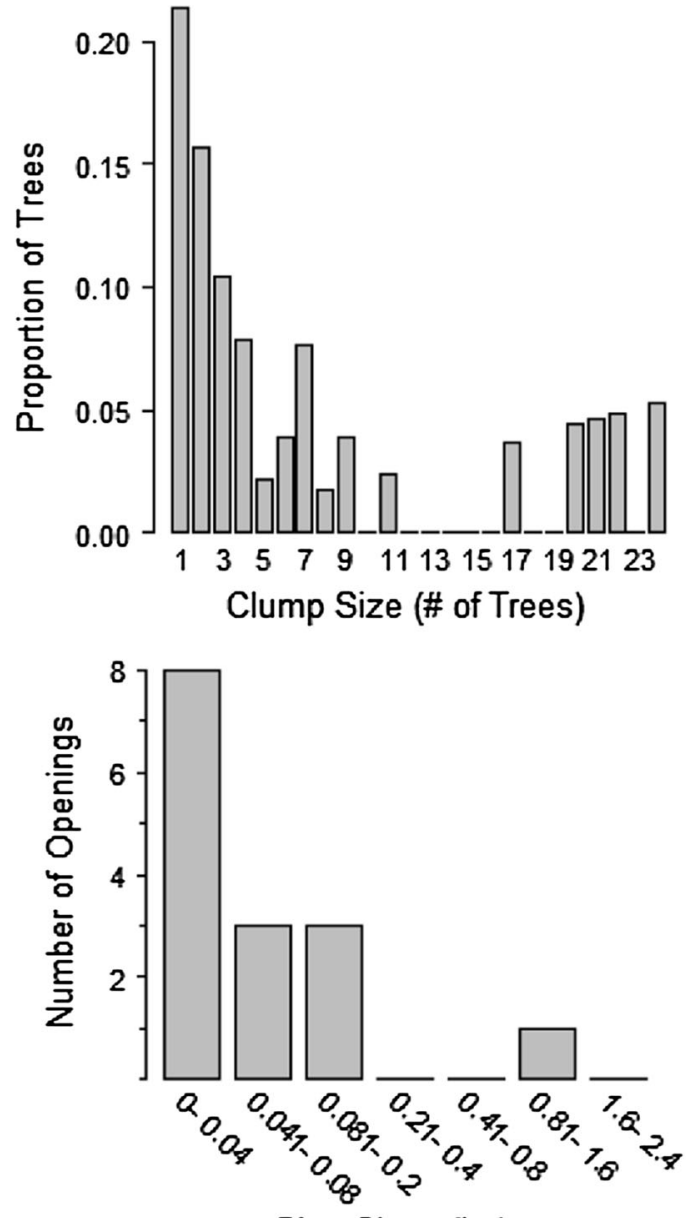

Size Class (ha)

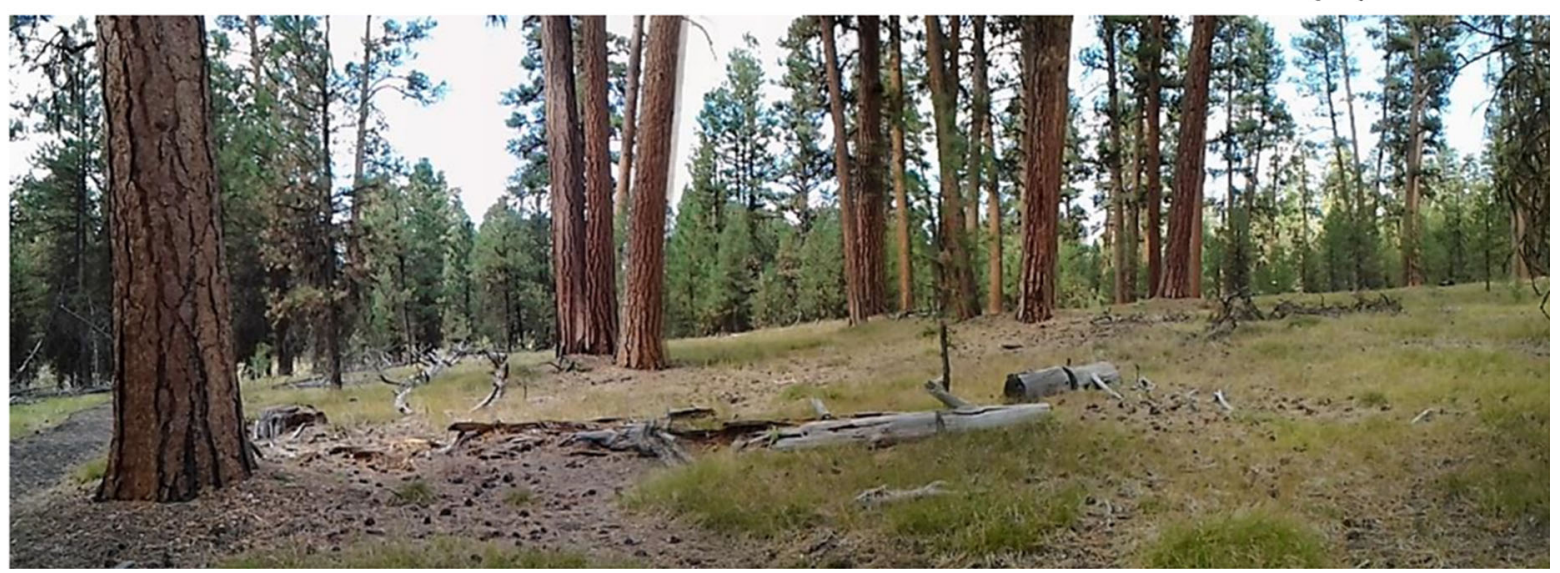

Fig. 10 Stem map (top left panel) and corresponding clump and opening size distributions (right panels) from a 4 ha plot of a reconstructed $1880 \mathrm{CE}$ ponderosa pine forest on the FremontWinema NF, Oregon. Background color gradient shows the distance to nearest tree. A $3 \mathrm{~m}$ crown radius was used to project tree crowns on all trees, and a fixed distance of $6 \mathrm{~m}$ was used to identify clumps because most mature trees have interlocking crowns at this distance. Large openings are shown with a dashed line. Note the sinuous shape of the openings. The bottom photo illustrates the clumpiness of the current plot conditions 
Box 4 Recommended adaptations to conventional silviculture

Recent landscape reconstructions at meso-and fine-scales (Churchill et al. 2013; Hessburg et al. 1999b; Collins et al. 2011, 2015; Larson and Churchill 2012; North et al. 2009; Lydersen and North 2012; Stephens et al. 2008; 2015; Taylor 2010) suggest that three adaptations are needed to conventional silviculture:

(1) Operational treatment units, whether mechanical or prescribed fire, should (re)create ranges and distributions of vegetation patch sizes that are characteristic of an ecoregion (Collins and Stephens 2010; Perry et al. 2011; Reynolds et al. 2013; Stine et al. 2014).

(2) Patches should be tailored to ridge, valley, and aspect topographies to achieve these patch size distributions (as above, Lydersen and North 2012; Moritz et al. 2011; Stine et al. 2014).

(3) Within patches, patterns of individual trees, tree clumps and gaps should reflect the fine-scale heterogeneity that would be expected given the natural disturbance regimes and biophysical setting (North et al. 2009; Sánchez Meador et al. 2011; Churchill et al. 2013; Kane et al. 2014; Fig. 10).

Restoring patterns across scales mimics the template that historically maintained species diversity and ecosystem functions thereby preparing the landscape for future disturbances.

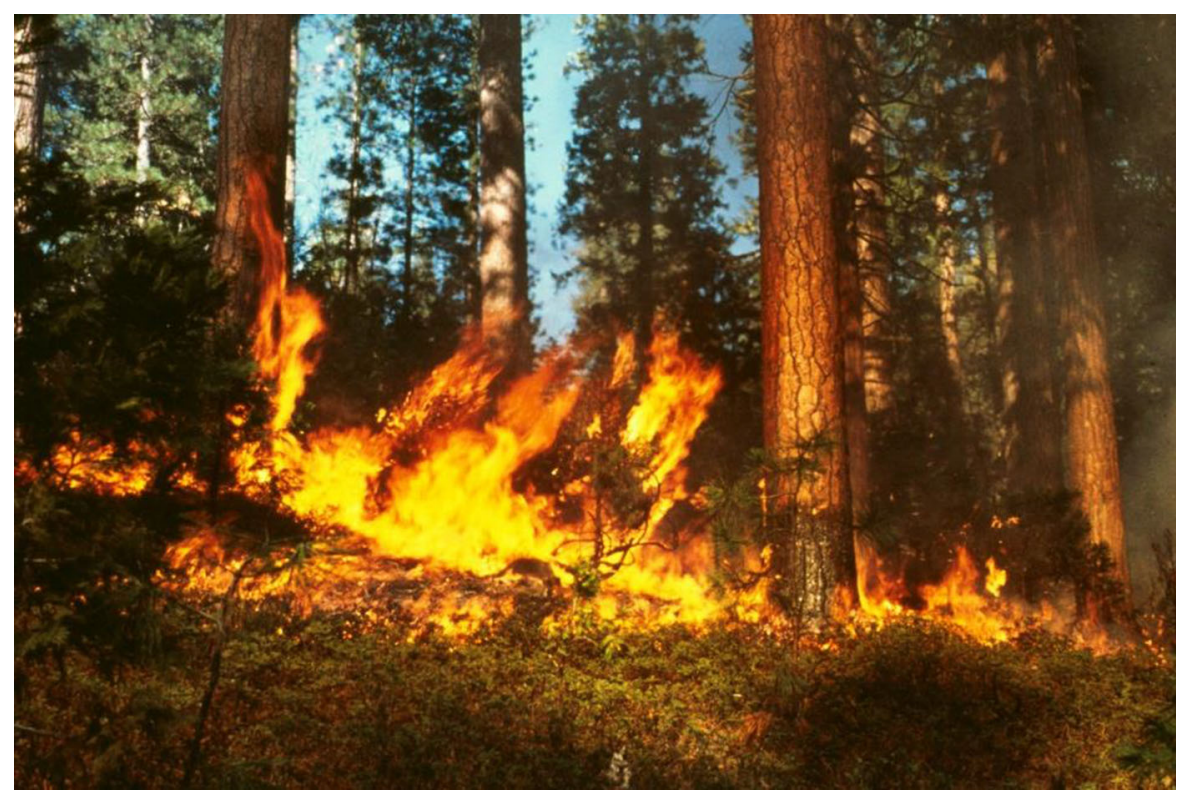

Fig. 11 Widely distributed large and old trees historically provided a critical structural backbone to forest landscapes (Table 1). Historically, these old trees consisted of early seral ponderosa pine and Jeffrey pine, western larch, giant sequoia, and Douglas-fir, which displayed the thickest outer bark, but also large sugar pine, western white pine, and incense-cedar,

of adjacent physical and environmental barriers to fire spread (Olson and Agee 2005; Camp et al. 1997).

Their long period of landscape service as live trees (e.g., 250-400 year), snags (30-100 year), logs (100-200 year), mulch (0-100 year), and soil carbon or charcoal (100-1000s year, Deluca and Aplet 2008) made large, old trees building blocks of the regional landscape. In addition, they are vital to many wildlife and fish habitats ( Foster et al. 1998; Franklin et al. which displayed a thinner outer bark, and were more easily scarred and killed by basal scorching. Large trees occurred in either open park-like or closed multi-story old forest patches, or they existed as a remnant of former forest conditions after a stand replacing fire with more than 70-75\% overstory mortality effects

2000; Hunter 2005; Agee and Skinner 2005; Reeves and Bisson 2009), and the legacy of large dead wood from wildfires and bark beetle outbreaks is a particularly important driver of habitat condition in the streams of many forested watersheds (Gregory et al. 2003). However, in some forests that experience frequent, low to moderate intensity fires, repeated fires can consume much of the down wood, leaving overall densities of these structural elements relatively low 
Table 1 The percentage of four sampled ecoregional areas with medium- and large-sized trees in the overstory, in each of three crown cover classes

\begin{tabular}{|c|c|c|c|c|c|c|c|c|}
\hline \multirow[t]{3}{*}{ Ecoregion } & \multicolumn{8}{|c|}{ Percentage area with medium- ${ }^{\mathrm{a}}$ and large-sized ${ }^{\mathrm{b}}$ trees by crown cover $(\mathrm{CC})$ class } \\
\hline & \multicolumn{2}{|c|}{$10-30 \% \mathrm{CC}^{\mathrm{c}}$} & \multicolumn{2}{|c|}{$40-60 \% \mathrm{CC}$} & \multicolumn{2}{|c|}{$>60 \% \mathrm{CC}$} & \multicolumn{2}{|c|}{ Total $\%$ area } \\
\hline & $\mathrm{H}^{4}$ & $\mathrm{C}$ & $\mathrm{H}$ & $\mathrm{C}$ & $\mathrm{H}$ & $\mathrm{C}$ & $\mathrm{H}$ & $\mathrm{C}$ \\
\hline Blue mountains & 23.3 & 18.4 & 11.9 & 6.7 & 4.5 & 2.1 & 39.6 & 27.2 \\
\hline Northern glaciated Mountains & 11.2 & 11.2 & 7.1 & 6.7 & 3.8 & 6.3 & 22.0 & 24.2 \\
\hline Northern cascades & 18.2 & 18.2 & 15.0 & 12.7 & 8.8 & 6.9 & 41.9 & 37.9 \\
\hline Southern cascades & 23.3 & 17.9 & 15.1 & 18.9 & 2.0 & 7.5 & 40.3 & 44.3 \\
\hline
\end{tabular}

Values in bold typeface indicate a significant reduction. Data are from the Interior Columbia Basin project (Hessburg et al. 1999a). Early twentieth-century conditions are highlighted in gray

${ }^{\text {a }}$ Medium trees $=40.5-63.5 \mathrm{~cm} \mathrm{DBH}$

b Large trees $\geq 63.5 \mathrm{~cm} \mathrm{DBH}$

${ }^{\mathrm{c}} \mathrm{CC}=$ denotes actual crown cover class, where maximum $\mathrm{CC}=100 \%$. Crown cover was photo-interpreted in $10 \%$ increments, and class percentages were expressed as class midpoints; e.g., $10 \%=5$ to $14 \% \mathrm{CC}, 20 \%=15$ to $24 \% \mathrm{CC}$ (Hessburg et al. 1999b). Crown cover classes above are regroupings of the decile classes

${ }^{\mathrm{d}} \mathrm{H}, \mathrm{C}=$ historical, current conditions, respectively

and patchily distributed. For example, this was observed in northwestern Mexico, where spatial variability in dead wood resources was measured in Jeffrey pine-mixed-conifer forests with relatively intact fire regimes (Stephens 2004; Stephens et al. 2007).

Table 1 shows the historical percentage area of four fire-prone provinces in eastern Oregon and Washington with remnant medium- and large-sized old trees. These data show that remnant medium- and large-sized old trees occupied partial overstories of up to $40 \%$ of patches, regardless of their successional condition. Early twentieth century timber inventories show that $68 \%$ of the Warm Springs and Klamath Indian reservations in central Oregon had at least 12 trees per hectare over $53 \mathrm{~cm}$ diameter at breast height (Hagmann et al. 2013, 2014). Their widespread presence suggested that remnant old trees were prevalent and important features of fire-prone landscapes.

\section{Implication}

Retain and expand on existing relict trees, old forests, and post-disturbance large snags and down logs in these types. In many dry pine and mixed-conifer landscapes, restoring the pattern and abundance of old trees and old forests should be a central theme of both regional and local landscape planning (Franklin and Johnson 2012; Franklin et al. 2013; USFS 2012; Spies et al. 2006). In other locations, recent bark beetle outbreaks and wildfires have created an abundance of snags; the largest among these are especially useful to retain as snag and down wood structure. Most current USFS Standards and Guidelines in Forest-level planning call for average snag and down wood conditions replicated over thousands of ha. Observations of patchily distribution snags and downed wood associated with frequent fire regimes argue against uniform prescriptions in dry forest landscapes (Holden et al. 2007; North et al. 2009). Local landscape restoration projects should increase abundance of closed canopy, old forest patches, especially in refugial settings (e.g. Franklin et al. 2013). To improve their longevity, restoration projects can be used to help provide firetolerant contexts surrounding them, (Box 5).

\section{Principle 7}

Land ownership, allocation, management and access patterns disrupt landscape and ecosystem patterns. Land ownership and allocation boundaries within ownerships are a byproduct of historical social and political decisions that were indifferent to the underlying ecology. The sum of these decisions and subsequent management differences produced a landscape fragmented by ownership and allocation (Fig. 12). Disparate and contradictory goals across land allocations and ownerships create untenable management situations (Rieman et al. 2015). For 
Box 5 Protect remaining live old trees and retain large old trees and snags after fires

Restorative management activities in many dry pine and mixed conifer landscapes should maintain existing patches of old forests, and retain remnant medium- and large-sized early seral trees where they occur. To improve the longevity of larger early seral trees, restorative activities would include thinning and removing neighboring shade-tolerant trees to reduce competition for water and nutrients, and removing nearby surface and ladder fuels to reduce fire intensities that would threaten their long-term survival. Furthermore, many south-facing aspects and ridgetops no longer support a characteristic abundance of early seral trees of any size and age. These settings should be evaluated for their ability to support the long term survival of early seral trees as the climate warms and dries. If deemed suitable, such sites could be emphasized for re-establishing thriving new populations, which in turn can be maintained through natural or prescribed fires and/or mechanical fuels reduction. Many existing ponderosa pine plantations can be managed and tended for future old pines as well. Where post-fire fuels are a bonafide reburn concern, salvage treatments should focus on removal of small trees and emphasize retention of large-trees, both living and dead.

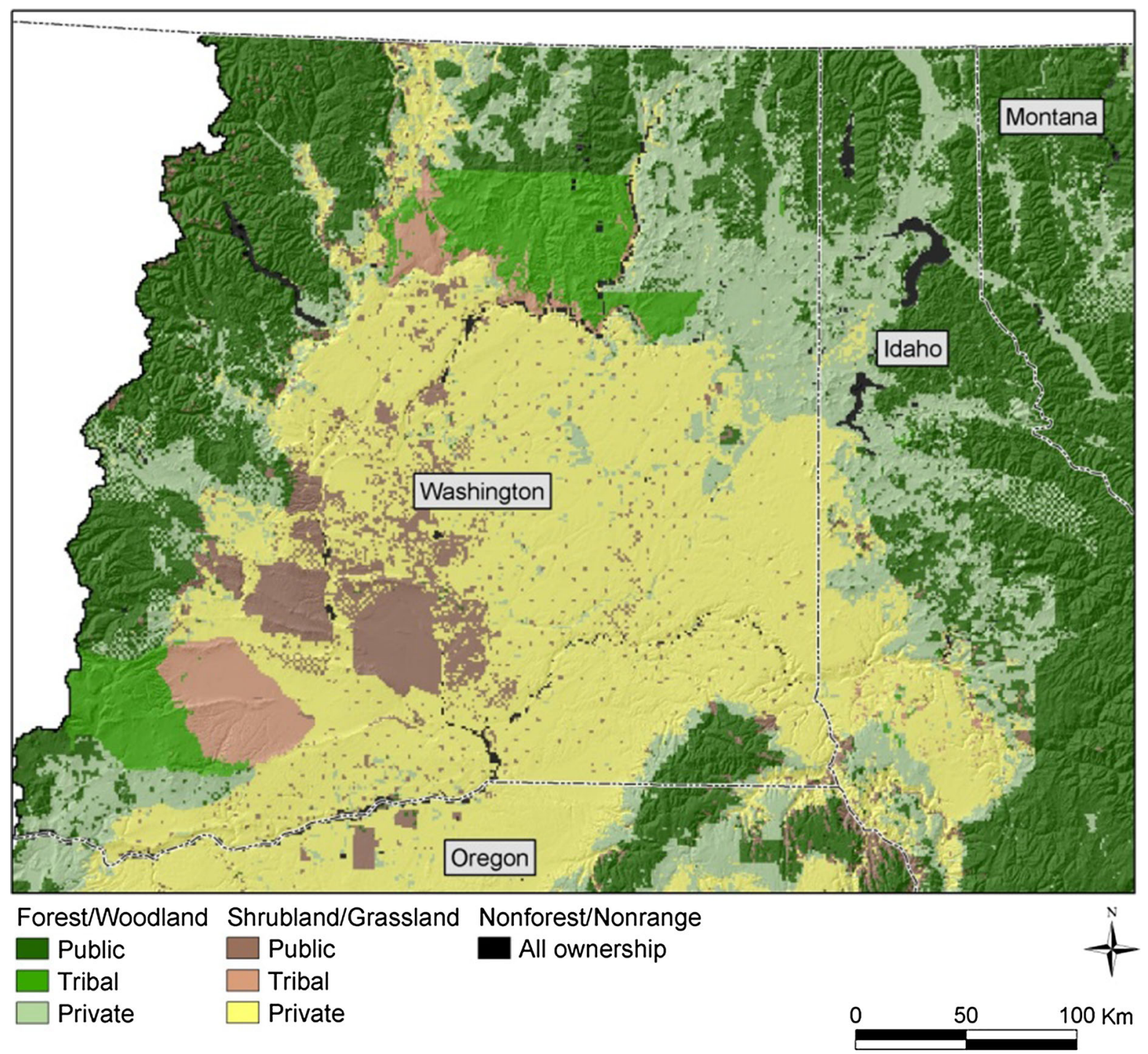

Fig. 12 Fragmentation of eastern Washington forests, grasslands, and shrublands by land ownership. Note that forests are shown in green and shrublands and grasslands are shown brown and yellow. Habitat fragmentation arises among mixed ownerships via varied management goals and histories, and resulting land and resource conditions 
Box 6 Decrease impacts of legacy roads

\begin{tabular}{l}
\hline Landscape restoration requires addressing the ongoing impacts of existing road networks on forest ecosystem processes and \\
functions. The effect of road networks on aquatic and terrestrial ecosystems is well established (Bisson et al. 2003; Forman 2003; \\
Gaines et al. 2003;Reed et al. 1996; Luce and Black 1999; Trombulak and Frissell 2000; Raphael et al. 2001). Past management has \\
left extensive and expensive legacy road networks, which are now declining in condition. These roads deliver chronic sediment to \\
nearby rivers and streams, and disrupt flow regimes. Deferred maintenance on retained roads yields persistent adverse impacts to \\
fish and wildlife habitats. In addition, road systems function as alternative drainage networks, which significantly disrupt the timing \\
and magnitude of flows and subsurface hydrology. However, not all roads are equally damaging or influential. Instead, most of the \\
chronic sediment, channel confinement, barrier, and flow issues are associated with a fraction of the existing network, and these \\
roads are readily identifiable. Landscape restoration projects should prioritize elimination, upgrading, or movement of these most \\
damaging roads. Roads located in valley-bottom settings that restrict normal floodplain functioning are among those most damaging \\
to aquatic habitat. Removal of these roads and floodplain restoration is especially important to recovering native aquatic species, \\
and will require planning and coordination across ownerships and interest groups.
\end{tabular}

example, fire management objectives often differ on either side of a wilderness boundary (Knight and Landres 1998). Likewise, land use zoning has resulted in a confusing set of regulations that apply inconsistent environmental protections across different ownership types. As a consequence, today's disturbance and climate change vulnerabilities, terrestrial and aquatic species habitat connectivity, and road system issues cannot be resolved by any landowner working in isolation (Box 6).

\section{Implication}

Work collaboratively to develop restoration projects that effectively work across ownerships, allocations, and access needs. Landscape prescriptions must be implemented at a relatively broad scale to be ecologically effective, particularly in the context of restoring disturbance regimes. To be socio-politically effective, restoration plans need cross-boundary collaboration and problem solving (Tabor et al. 2014; Wondolleck and Yaffee 2000). Collaboration on a project from conception through design, implementation, and monitoring can expand options for management in the long run, and create synergies that are otherwise unavailable. Moreover, litigation history shows that restoration planning greatly benefits from involving all stakeholder groups who have a vested interest in the outcomes (Culhane 2013). Partner interactions create the opportunity to daylight concerns before they become litigious, and create landscape-level prescriptions that can accommodate them by design (Larson et al. 2013).

Forest collaboratives are well suited to crossownership and multi-stakeholder planning (Cheng and Sturtevant 2012; Charnley et al. 2014), and there are significant opportunities to coordinate activities that exceed the capacities of individual landowners. For example, in the state of Washington, USA, the northern spotted owl is federally listed as an endangered species. Federal land managers and the Washington Department of Fish and Wildlife manage most of the current nesting, roosting, and foraging habitats, while dispersal habitats often occur on intermingled Washington State Department of Natural Resources trust lands (USFWS 2012), which are managed as working forests. Road maintenance, removal, and closures, and restoration of fish and wildlife habitats and connectivity all require a similar high degree of coordination.

\section{Implications emerging from all seven principles}

Emerging from all seven principles is the idea that landscape prescriptions are foundational to restoration. Landscape prescriptions are a way for managers to implement the principles outlined above and to move beyond stand-centered forest management.

A landscape prescription provides guidance for landscape composition, structure, and spatial arrangement in terms of the elements comprising the next lower level of the hierarchy. We identified four hierarchical levels in Principle 1; hence landscape prescriptions are needed at three levels:

- Large-scale ecoregional prescriptions are important to reconnecting broad habitat networks and rescaling disturbance processes.

- Local landscape prescriptions define objectives for successional patch types, size distributions, and 
spatial arrangements across the topographic template.

- Patch-level prescriptions describe target conditions within successional patches.

Linked evaluations and prescriptions are needed at each level where landscape change has been significant and restoration is warranted.

Ecoregional prescriptions are strategic - they highlight priority areas for reconnecting habitats and conditions under which wildfires may/may not contribute to restoring desirable local landscape patterns (North et al. 2012a). Ecoregional prescriptions should identify areas where post-disturbance silviculture or burning may be appropriate/inappropriate, and where wildfires can contribute to restoration (Allen et al. 2002; Reinhardt et al. 2008; Peterson et al. 2015). Ecoregional prescriptions should provide clear guidance for reestablishing large-scale ecoregional connectivity for wide-ranging and migratory aquatic and terrestrial species.

Local landscape prescriptions are tactical-they identify specific project areas where treatments can begin to restore ecoregional patterns and processes for multiple resources (Box 7). Local landscape

Box 7 A local landscape prescription on the Colville National Forest

We provide here an example landscape prescription from a 9500 ha mixed-conifer watershed in northeast Washington that historically supported a predominantly mixed-severity fire regime, but has been modified by fire suppression, grazing, and logging. The landscape prescription was derived from an equally-weighted HRV and FRV departure analysis that was specific to the watershed (see Hessburg et al. 2013). The basis for the prescription is thus, one part departure from HRV pattern conditions, and one part climate change adaptation, in a bet-hedging strategy to conserve maximal future options. The landscape prescription provides clear, spatially-mapped recommendations to managers on where to modify forest structure, composition, and the overall distribution of patch sizes. The prescription intentionally avoids statements about average stand conditions to facilitate creation of heterogeneity at multiple spatial scales. Improved alignment of cover type and structure conditions with topography and biophysical settings, and more naturally occurring disturbance regimes (Fig. 13), were additional goals. Treatment type for different portions of the watershed (e.g. no-treatment, mechanical, prescribed or wildfire) was also identified based on treatment need, road access, and other factors. For example, the prescription for roadless areas of the watershed was to leave them alone to grow into large tree, closed canopy forest in cool, moist refugial topographic locations, and to allow managed wildfire to create stand initiation and open canopy patches in drier areas, where feasible. An abridged version of the prescription follows:

Objectives for the whole watershed:

- Reduce landscape fragmentation by increasing patch size of most cover-structure types, as well as connectivity in some cases.

- For all forested cover types, consolidate and expand approximately $1 / 2$ of the small patches (1-50 ha) into 100-400 ha patches, where possible.

In the dry forest area of the watershed:

- Increase the area of the ponderosa pine (Pinus ponderosa Dougl. ex Laws.) cover type with large and old over story trees, from 3 to $12-15 \%$ of the watershed area.

- Increase the area of woodland cover types from less than 1 to $2-3 \%$ of the watershed area. Increase the range of patch sizes to 40-125 ha, where possible.

- Reduce the amount of the Douglas-fir (Pseudotsuga menziesii (Mirb.) Franco) cover type from 25 to 8-12\% of the watershed area, especially in young forest multistory and stem exclusion structures.

In the mesic and cold forest area of the watershed:

- Increase the area of the ponderosa pine cover type from 2 to 8-10 \% of the watershed area. Promote old forest structure as well as stand initiation using wild and prescribed fires to fullest advantage.

- Increase the area of the Douglas-fir cover type from 8 to 20-30 \% of the watershed area. Promote open and close canopy old forest and reduce stem exclusion structure.

- Increase the patch size range of lodgepole pine (Pinus contorta Dougl. ex. Loud.) and western larch (Larix occidentalis Nutt.). Increase area in stand initiation.

- Increase the area of hardwood, shrub, herb, and woodland cover types from less than $1 \%$ of the area to 4-7\% of the watershed area. Increase the range of patch sizes to 10-25 ha.

- Reduce the area of the subalpine fir (Abies lasiocarpa (Hook.) Nutt.) cover type from 12 to 3-4\% of the watershed area, and that of the western redcedar (Thuja plicata Donn ex D. Don) cover type from 6 to 2-3\% of the watershed area.

Outside areas of old multi-story forest in dry, mesic, and cold forest, reduce the total area with high fuel loads (surface, ladder, and crown fuels) and increase the total area and size of patches with low fuel loads, especially on south-facing aspects and on ridgetops. 
prescriptions provide guidance about how to arrange different successional patches across the topographic template (Principle 2), the target patch size distributions (Principle 4), and how to protect and increase abundance of legacy old trees (Principle 6). Articulating how silvicultural treatments, prescribed fire, and wildfire can work together to restore disturbance regimes (Principle 3) will be necessary for a successful local landscape prescription. Terrestrial and aquatic habitat and road system restoration opportunities should be linked in local landscape prescriptions to take advantage of simultaneous problem-solving opportunities (Rieman et al. 2010). For example, local prescriptions can identify harmful road segments and fish passage barriers, opportunities to expand local fish strongholds and rebuild larger, more productive fish and wildlife habitat patches (sensu Rieman et al. 2000, 2010).

Patch-level silvicultural prescriptions provide targets for the structure, density, composition, and pattern of a patch, or group of patches, that are tailored to the current vegetation conditions and biophysical setting of the site (Principle 5). Targets for heterogeneity within patches can be expressed in terms of the numbers and sizes of widely-spaced individual trees, tree clumps, and openings (Churchill et al. 2013), or using other metrics and tools (e.g. Jain et al. 2008; Reynolds et al. 2013). Treatment units, which flow from patch-level prescriptions, are the portions of a local landscape that will be treated to achieve the desired targets. They can comprise a single patch, part of a patch, multiple patches, or even cut across patch boundaries. Critically, treatment units should not define landscape pattern as they currently do in many landscapes.

\section{Summary}

Managing fire-prone landscapes today to increase their climate- and fire-resilience poses immense challenges to managers, in planning and execution (North et al. 2012a, b). The current management environment is internally and externally polarized by mistrust, and a concern that land managers may never make a paradigm shift to sustainable ecosystem management (sensu Grumbine 1994; Spies et al. 2012, 2014; Dunlap and Mertig 2014). Here we argue that the time for that shift has come, and many partners of federal lands wish to help it along (Brown et al. 2004; Cheng and Sturtevant 2012; Charnley et al. 2014).

We provide core principles gleaned from recent research to advance management planning and treatment design to better incorporate natural processes, climate change, and operational limitations into management. We emphasize pine and mixed-conifer forests of the interior Pacific, but the principles and implications we outline are applicable elsewhere, especially to the dry pine and mixed-conifer forests of the southwestern US and Rocky Mountain regions. Central to our proposed framework are the notions that:

- Prior to the modern management era, western forest and rangeland landscapes were spatially heterogeneous at several scales.

- This heterogeneity resulted from native ecological and physical processes and their interactions with forest habitat and successional patterns.

- These processes created habitat and networking conditions to which native flora and fauna are adapted.

- Forest and rangeland conditions and their associated species were adaptable and resilient to shifts in climate and recurrent contagious disturbances.

- Multi-scale heterogeneity has been altered in many areas over the course of management.

- Disturbance processes, particularly wildfires and bark beetle outbreaks, will continue to be primary determinants of patterns in managed and unmanaged landscapes.

- Future climatic changes may surpass those experienced in the Inland Pacific region during the last interglacial. In that event, historical insights can inform our understanding of ecosystem responses to climate forcing, but management adaptations will need to be forward-looking.

- Collaboration on restorative management among managers, stakeholders, and scientific disciplines is essential because forest landscapes are coupled terrestrial and aquatic, social and ecological systems, and people have a stake in the outcomes. Collaboration and negotiation are imperative precursors to management.

Our principles stress the importance of scale and the interconnectedness of landscapes across scales. The traditional view of managing stands of trees in isolation is a relic of the past. 

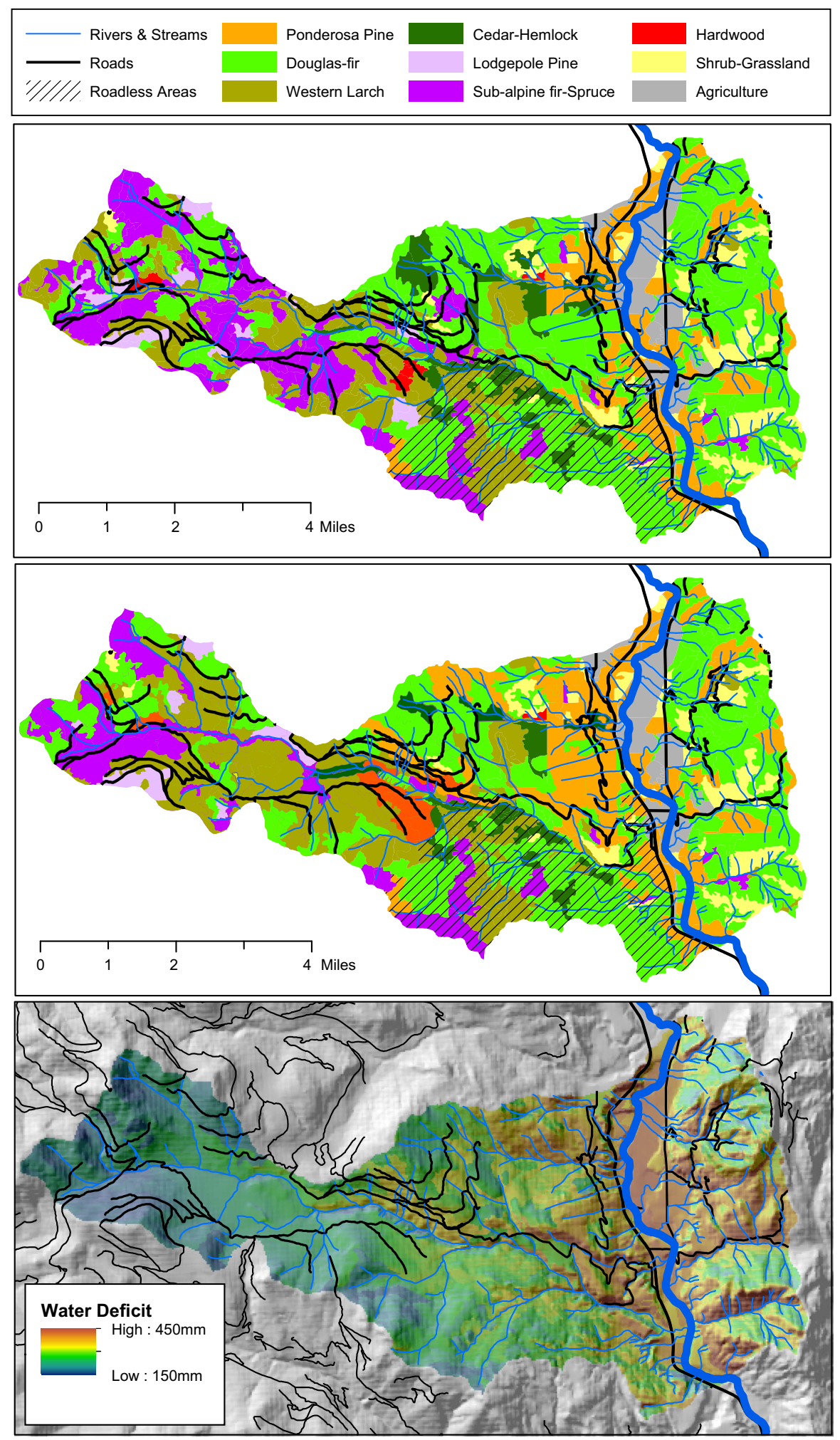
4Fig. 13 Cover types and soil moisture deficit for the Orient subwatershed on the Colville National Forest in North-Central Washington (9500 ha). Top panel shows current cover types and middle panel shows projected cover types after potential treatments guided by a landscape prescription. Cover types are named after the dominant species, but contain multiple species. Potential treatments are not proposed treatments. Proposed treatments will be released for public comment and evaluated during a formal NEPA planning process. Potential treatments included mechanical thinning and prescribed fire. The major goals of the landscape prescription were to increase patch sizes and shift cover and structure types to species better aligned with the topography and biophysical conditions as illustrated on the bottom panel-only changes in cover types are shown here. Climatic water deficit on the bottom panel was calculated using modified Thornthwaite methods described in Churchill et al. (2013)

Landscape restoration will require the integrated use of vegetation treatments, prescribed and managed fires to achieve the necessary changes in landscape patterns, at scales broad enough to be meaningful. Management can be informed by natural landscape patterns that result from interactions between biotic communities, disturbances, and physiographic environments (DeLong and Tanner 1996). Such conditions can be quantified using past vegetation patterns HRV, and where appropriate, climate change analogue conditions, and used to help craft landscape prescriptions (Box 7) that provide guidance on the amount, distribution, and pattern of successional conditions to create through management actions.

Wildfires and insect outbreaks are an inevitable part of future landscapes. Future management should aim to restore more resilient vegetation patterns that can help to realign the severity and patch sizes of these disturbances, promote natural post-disturbance recovery, reduce the need for expensive active management, and drastically reduce the role and need of fire suppression.

Acknowledgments The authors thank Keith Reynolds, Cameron Thomas, Richy Harrod, Rachel White, and the anonymous reviewers for helpful reviews. We thank James Pass and the staff from the Three Rivers Ranger District on the Colville NF for working with us on the landscape evaluation and prescription for the Orient Watershed. We also thank the PNW, Rocky Mountain, and PSW Research Stations, the Joint Fire Sciences Program, National Science Foundation (Award \#1256819), and the National Fire Plan for generous support of the many research studies synthesized in this review.

Open Access This article is distributed under the terms of the Creative Commons Attribution 4.0 International License (http:// creativecommons.org/licenses/by/4.0/), which permits unrestricted use, distribution, and reproduction in any medium, provided you give appropriate credit to the original author(s) and the source, provide a link to the Creative Commons license, and indicate if changes were made.

\section{References}

Agee JK (1993) Fire ecology of pacific northwest forests. Island Press, Covelo

Agee JK (1998) The landscape ecology of western forest fire regimes. Northwest Sci 72:24-34

Agee JK, Skinner CN (2005) Basic principles of forest fuel reduction treatments. For Ecol Manag 211:83-96

Allen CD, Savage M, Falk DA, Suckling KF, Swetnam TW, Schulke T, Stacey PB, Morgan P, Hoffman M, Klingel JT (2002) Ecological restoration of southwestern ponderosa pine ecosystems: a broad perspective. Ecol Appl 12:1418-1433

Allen CD, Macalady AK, Chenchouni H, Bachelet D, McDowell N, Vennetier M, Kitzberger T, Rigling A, Breshears DD, Hogg EH, Gonzalez P, Fensham R, Zhang Z, Castro J, Demidova N, Limp J-H, Allard G, Running SW, Semerci A, Cobb N (2010) A global overview of drought and heatinduced tree mortality reveals emerging climate change risks for forests. For Ecol Manag 259:660-684

Arno SF, Gruell GE (1986) Douglas-fir encroachment into mountain grasslands in southwestern Montana. J Range Manag 39:272-276

Arnst A (1985) We climbed the highest mountains. Fernhopper Press, Portland

Baker WL (2012) Implications of spatially extensive historical data from surveys for restoring dry forests of Oregon's eastern Cascades. Ecosphere, 3(3) art23

Belote RT, Aplet GH (2014) Land protection and timber harvesting along productivity and diversity gradients in the Northern Rocky Mountains. Ecosphere, 5(2) art17

Belsky JA, Blumenthal DM (1997) Effects of livestock grazingon stand dynamics and soils in upland forests of the Interior West. Conserv Biol 11:315-327

Bentz BJ, Régnière J, Fettig CJ, Hansen EM, Hayes JL, Hicke JA, Kelsey RG, Negrón JF, Seybold SJ (2010) Climate change and bark beetles of the western United States and Canada: direct and indirect effects. Bioscience 60:602-613

Bisson PA, Rieman BE, Luce C, Hessburg PF, Lee DC, Kershner JL, Reeves GH, Gresswell RE (2003) Fire and aquatic ecosystems of the western USA: current knowledge and key questions. For Ecol Manag 178:213-229

Bisson PA, Dunham JB, Reeves GH (2009) Freshwater ecosystems and resilience of Pacific salmon: habitat management based on natural variability. Ecol Soc 14(1):45

Bosworth D (2006) Investing in the future: ecological restoration and the US forest service. J For 105:208-211

Brown RT, Agee JK, Franklin JF (2004) Forest restoration and fire: principles in the context of place. Conserv Biol 18:903-912

Butler WH (2013) Collaboration at arm's length: navigating agency engagement in landscape-scale ecological restoration collaboratives. J For 111:395-403

Camp A, Oliver C, Hessburg PF, Everett RL (1997) Predicting late-successional fire refugia pre-dating European settlement in the Wenatchee Mountains. For Ecol Manag 95:63-77 
Cansler CA, McKenzie D (2014) Climate, fire size, and biophysical setting control fire severity and spatial pattern in the northern Cascade Range, USA. Ecol Appl 24:1037-1056

Chapin FS III, Carpenter SR, Kofinas GP, Folke C, Abel N, Clark WC, Olsson P, Stafford Smith DM, Walker BH, Young OR, Berkes F, Biggs R, Grove JM, Naylor RL, Pinkerton E, Steffen W, Swanson FJ (2010) Ecosystem stewardship: sustainability strategies for a rapidly changing planet. Trends Ecol Evol 25:241-249

Charnley S, Sheridan TE, Nabhan GP (eds) (2014) Stitching the west back together: conservation of working landscapes. University of Chicago Press, Chicago

Cheng AS, Sturtevant VE (2012) A framework for assessing collaborative capacity in community-based public forest management. Environ Manage 49:675-689

Churchill DJ, Larson AJ, Dahlgreen MC, Franklin JF, Hessburg PF, Lutz JA (2013) Restoring forest resilience: from reference spatial patterns to silvicultural prescriptions and monitoring. For Ecol Manag 291:442-457

Collins BM, Stephens SL (2010) Stand-replacing patches within a mixed severity fire regime: quantitative characterization using recent fires in a long-established natural fire area. Landsc Ecol 25:927-939

Collins BM, Miller JD, Thode AE, Kelly M, van Wagtendonk JW, Stephens SL (2009) Interactions among wildland fires in a long-established Sierra Nevada natural fire area. Ecosystems 12:114-128

Collins BM, Everett RG, Stephens SL (2011) Impacts of fire exclusion and recent managed fire on forest structure in old growth Sierra Nevada mixed-conifer forests. Ecosphere. doi:10.1890/ES11-00026.1

Collins BM, Lydersen JM, Everett RG, Fry DF, Stephens SL (2015) Novel characterization of landscape-level variabilty in historical vegetation structure. Ecol Appl 16:1267-1276

Coop JD, Givnish TJ (2007) Spatial and temporal patterns of recent forest encroachment in montane grasslands of the Valles Caldera, New Mexico, USA. J Biogeogr 34:914-927

Crookston NL, Rehfeldt GE, Dixon GE, Weiskittel AR (2010) Addressing climate change in the forest vegetation simulator to assess impacts on landscape forest dynamics. For Ecol Manag 260:1198-1211

Culhane PJ (2013) Public lands politics: interest group influence on the forest service and the bureau of land management. Routledge, New York

Delong CS, Tanner D (1996) Managing the pattern of forest harvest: lessons from wildfire. Biodiv Conserv 5:1191-1205

DeLuca TH, Aplet GH (2008) Charcoal and carbon storage in forest soils of the Rocky Mountain West. Front Ecol Environ 6:18-24

Dickinson Y (2014) Landscape restoration of a forest with a historically mixed-severity fire regime: what was the historical landscape pattern of forest and openings? For Ecol Manag 331:264-271

Dobrowski SZ, Thorne JH, Greenberg JA, Safford HD, Mynsberge AR, Crimmins SM, Swanson AK (2011) Modeling plant ranges over 75 years of climate change in California, USA: temporal transferability and species traits. Ecol Mono 81:241-251

Dodd NL, Schweinsburg RE, Boe S (2006) Landscape-scale forest habitat relationships to tassel-eared squirrel populations: implications for ponderosa pine forest restoration. Restor Ecol 14(4):537-547
Dodson EK, Peterson DW, Harrod RJ (2008) Understory vegetation response to thinning and burning restoration treatments in dry conifer forests of the eastern Cascades, USA. For Ecol Manag 255(8):3130-3140

Duncan SL, McComb BC, Johnson KN (2010) Integrating ecological and social ranges of variability in conservation of biodiversity: past, present, and future. Ecol Soc 15(1):5

Dunlap RE, Mertig AG (2014) American environmentalism: The US environmental movement, 1970-1990. Taylor \& Francis, London

Ellison AM, Bank MS, Clinton BD, Colburn EA, Elliot K, Ford CR, Foster DR, Kloeppel BD, Knoepp JD, Lovett GM, Mohan J, Orwig DA, Rodenhouse NL, Sobczak WV, Stinson KA, Stone JK, Swan CM, Thompson J, Von Holle B, Webster JR (2005) Loss of foundation species: consequences for the structure and dynamics of forested ecosystems. Front Ecol Environ 3:479-486

Falk D, Miller C, McKenzie D, Black A (2007) Cross-scale analysis of fire regimes. Ecosystems 10:809-823

Fettig CJ, Klepzig KD, Billings RF, Munson AS, Nebeker TE, Negrón JF, Nowak JT (2007) The effectiveness of vegetation management practices for prevention and control of bark beetle infestations in coniferous forests of the western and southern United States. For Ecol Manag 238(1): 24-53

Folke C, Hahn T, Olsson P, Norberg J (2005) Adaptive governance of social-ecological systems. Ann Rev Environ Res 30:441-473

Forman RT (2003) Road ecology: science and solutions. Island Press, Washington

Foster DR, Knight DH, Franklin JF (1998) Landscape patterns and legacies resulting from large, infrequent forest disturbances. Ecosystems 1:497-510

Franklin JF, Forman RT (1987) Creating landscape patterns by forest cutting: ecological consequences and principles. Landscape Ecol 1:5-18

Franklin JF, Johnson KN (2012) A restoration framework for federal forests in the Pacific Northwest. J For 110:429-439

Franklin JF, Lindenmayer D, MacMahon JA, McKee A, Magnuson J, Perry DA, Waide R, Foster D (2000) Threads of continuity. Conserv Pract 1(1):8-17

Franklin JF, Johnson KN, Churchill DJ, Hagmann K, Johnson D, Johnston J (2013) Restoration of dry forests in eastern Oregon: a field guide. Nat Conserv, Portland

Franklin JF, Hagmann RK, Urgenson LS (2014) Interactions between societal goals and restoration of dry forest landscapes in western North America. Landscape Ecol 29:1-11

Frelich LE, Reich PB (1999) Mini-reviews: neighborhood effects, disturbance severity, and community stability in forests. Ecosystems 2:151-166

Fry DL, Stephens SL, Collins BM, North MP, Franco-Vizcaino E, Gill S (2014) Contrasting spatial patterns in active-fire and fire-suppressed Mediterranean climate old-growth mixed-conifer forests. PLoS ONE 9(2):e88985

Fulé PZ, Crouse JE, Roccaforte JP, Kalies EL (2012) Do thinning and/or burning treatments in western USA ponderosa or Jeffrey pine-dominated forests help restore natural fire behavior? For Ecol Manag 269:68-81

Gaines WL, Singleton PH, Ross RC (2003) Assessing the cumulative effects of linear recreation routes on wildlife habitats on the Okanogan and Wenatchee National Forests. 
USDA Forest Service, Pacific Northwest Research Station, PNW-GTR-586

Gregory S, Boyer KL, Gurnell AM (2003) The ecology and management of wood in world rivers. Am Fish Soc Symp 37:315-336

Grumbine RE (1994) What is ecosystem management? Conserv Bio 8:27-38

Habeck JR (1994) Using general land office records to assess forest succession in ponderosa pine/Douglas-fir forests in western Montana. Northwest Sci 68:69-78

Hagmann RK, Franklin JF, Johnson KN (2013) Historical structure and composition of ponderosa pine and mixedconifer forests in south-central Oregon. For Ecol Manag 304:492-504

Hagmann RK, Franklin JF, Johnson KN (2014) Historical conditions in mixed-conifer forests on the eastern slopes of the northern Oregon Cascade Range, USA. For Ecol Manag 330:158-170

Hampe A, Petit RJ (2005) Conserving biodiversity under climate change: the rear edge matters. Ecol Lett 8:461-467

Hargrove WW, Hoffman FM (2004) Potential of multivariate quantitative methods for delineation and visualization of ecoregions. Environ Manag 34:S39-S60

Harrod RJ, McRae BH, Hartl WE (1999) Historical stand reconstruction in ponderosa pine forests to guide silvicultural prescriptions. For Ecol Manag 114:433-446

Helms JA (1988) Forest vegetation management for conifer production. Wiley, New York

Hessburg PF, Agee JK (2003) An environmental narrative of Inland Northwest United States forests, 1800-2000. For Ecol Manage 178:23-59

Hessburg PF, Mitchell RG, Filip GM (1994) Historical and current roles of insects and pathogens in eastern Oregon and Washington forested landscapes. General Technical Report PNW-GTR-327. Portland: USDA-FS, Pacific Northwest Research Station

Hessburg PF, Smith BG, Salter RB (1999a) Detecting change in forest spatial patterns from reference conditions. Ecol Appl 9:1232-1252

Hessburg PF, Smith BG, Kreiter SD et al (1999b) Historical and current forest and range landscapes in the interior Columbia River Basin and portions of the Klamath and Great Basins: Part I: Linking vegetation patterns and landscape vulnerability to potential insect and pathogen disturbances. General Technical Report PNW-GTR-458. Portland: USDA-FS, Pacific Northwest Research Station, p 357

Hessburg PF, Smith BG, Salter RB, Ottmar RD, Alvarado E (2000a) Recent changes (1930's-1990's) in spatial patterns of interior northwest forests, USA. For Ecol Manag 136:53-83

Hessburg PF, Salter RB, Richmond M, Smith BG (2000b) Ecological subregions of the Interior Columbia Basin, USA. Appl Veg Sci 3:163-180

Hessburg PF, Agee JK, Franklin JF (2005) Dry mixed-coniferforests and wildland fires of the Inland Northwest: contrasting the landscape ecology of the pre-settlement and modern eras. For Ecol Manag 211:117-139

Hessburg PF, James KM, Salter RB (2007) Re-examining fire severity relations in pre-management era mixed-conifer forests: inferences from landscape patterns of forest structure. Landscape Ecol 22:5-24
Hessburg PF, Reynolds KM, Salter RB, Dickinson JD, Gaines WL, Harrod RJ (2013) Landscape evaluation for restoration planning on the Okanogan-Wenatchee National Forest, USA. Sustainability 5:805-840

Hessburg PF, Perry DA, Spies TA, Skinner CN, Stephens SL, Taylor AH, Franklin JF, McComb B, Riegel G (2015) Management of mixed severity forests in Washington, Oregon, and California. For Ecol Manag 262:703-717

Higgs E, Falk DA, Guerrini A, Hall M, Harris J, Hobbs RJ, Jackson ST, Rhemtulla JM, Throop W (2014) The changing role of history in restoration ecology. Front Ecol Environ 12:499-506

Hobbs RJ, Higgs E, Harris JA (2009) Novel ecosystems: implication for conservation and restoration. Trends Ecol Evol 24:599-605

Holden ZA, Morgan P, Rollins MG, Kavanagh K (2007) Effects of multiple wildland fires on ponderosa pine stand structure in two southwestern wilderness areas, USA. Fire Ecol 3:18-33

Holling CS (1992) Cross-scale morphology, geometry, and dynamics of ecosystems. Ecol Monogr 62:447-502

Hunter ML (2005) A mesofilter conservation strategy to complement fine and coarse filters. Conserv Biol 19:1025-1029

ISAB (2011) Using a comprehensive landscape approach for more effective conservation and restoration. Northwest Power and Conservation Council Report No. ISAB 2011-4. Portland. www.nwcouncil.org/fw/isab/isab2011-4/. Accessed 15 Aug 2013

Jain TB, Graham RT, Sandquist J, Butler M, Brockus K, Frigard D, Cobb D, Sup-Han H, Halbrook J, Denner R, Evans JS (2008) Restoration of northern Rocky Mountain moist forests: Integrating fuel treatments from the site to the landscape. pp 147-172 in USDA Forest Service, PNWGTR-733

Johnson EA (1992) Fire and vegetation dynamics: studies from the North American boreal forest. Cambridge University Press, Cambridge

Johnson EA, Miyanishi K (1995) The need for consideration of fire behavior and effects in prescribed burning. Restor Ecol 3:271-278

Jones JA, Swanson FJ, Wemple BC, Snyder KU (2000) Effects of roads on hydrology, geomorphology, and disturbance patches in stream networks. Conserv Biol 14:76-85

Kane VR, North MP, Lutz JA, Churchill DJ, Roberts SL, Smith DF, McGaughey RJ, Kane J, Brooks ML (2014) Assessing fire effects on forest spatial structure using a fusion of Landsat and airborne LiDAR data in Yosemite National Park. Remote Sens Environ 151:89-101

Kane VR, Lutz JA, Cansler A, Povak NA, Churchill DJ, Smith D, Kane JT, North MP (2015) Water balance and topography predict fire and forest structure patterns. For Ecol Manag 338:1-13

Keane RE, Parsons RA, Hessburg PF (2002) Estimating historical range and variation of landscape patch dynamics: limitations of the simulation approach. Ecol Model 151:29-49

Keane RE, Hessburg PF, Landres PB, Swanson FJ (2009) The use of historical range and variability (HRV) in landscape management. For Ecol Manag 258:1025-1037

Keiter RB (2005) Public lands and law reform: putting theory, policy, and practice in perspective. Utah Law Rev 1127:1173-1180 
Knight RL, Landres PB (1998) Stewardship across boundaries. Island Press, Washington

Kotliar NB, Wiens JA (1990) Multiple scales of patchiness and patch structure: a hierarchical framework for the study of heterogeneity. Oikos 59:253-260

Krieger D (2001) Economic value of forest ecosystem services: areview. The Wilderness Society, Washington

Küchler AW(1964) Potential natural vegetation of the conterminous United States. Manual to accompany the map (No. 36). American Geographical Society

Landres PB, Morgan P, Swanson FJ (1999) Overview of the use of natural variability concepts in managing ecological systems. Ecol Appl 9:1179-1188

Langston N (1995) Forest dreams, forest nightmares: the paradox of old growth in the Inland West. University of Washington Press, Seattle

Larson AJ, Churchill D (2012) Tree spatial patterns in fire-frequent forests of western North America, including mechanisms of pattern formation and implications for designing fuel reduction and restoration treatments. For Ecol Manag 267:74-92

Larson AJ, Belote RT, Williamson MA, Aplet GH (2013) Making monitoring count: project design for active adaptive management. J For 111:348-356

Lertzman KP, Fall J (1998) From forest stands to landscapes: spatial scales and the roles of disturbances. In: Peterson DL, Parker VT (eds) Ecological scale: theory and applications. Columbia University Press, New York, pp 339-367

Littell J, McKenzie D, Peterson D, Westerling A (2009) Climate and wildfire area burned in western US ecoprovinces, 1916-2003. Ecol Appl 19:1003-1021

Loehman RA, Clark JA, Keane RE (2011) Modeling effects of climate change and fire management on western white pine (Pinus monticola) in the northern Rocky Mountains, USA. Forests 2:832-860

Luce CH, Black TA (1999) Sediment production from forest roads in western Oregon. Water Resour Res 35:2561-2570

Lutz JA, van Wagtendonk JW, Franklin JF (2009) Twentiethcentury decline of large-diameter trees in Yosemite National Park, California, USA. For Ecol Manag 257:2296-2307

Lydersen JM, North MP (2012) Topographic variation in activefire forest structure under current climate conditions. Ecosystems 15:1134-1146

Lydersen JM, North MP, Knapp EE, Collins BM (2013) Quantifying spatial patterns of tree groups and gaps in mixed-conifer forests: reference conditions and long-term changes following fire suppression and logging. For Ecol Manag 304:370-382

Lydersen JM, North MP, Collins BM (2014) Severity of an uncharacteristically large wildfire, the Rim Fire, in forests with relatively restored frequent fire regimes. For Ecol Manag 328:326-334

Malamud BD, Morein G, Turcotte DL (1998) Forest fires: an example of self-organized critical behavior. Science 281:1840-1842

Marshall R (1928) The life history of some western white pine stands on the Kaniksu National Forest. Northwest Sci 2:48-53

McGarigal K, Romme WH (2012) Modeling historical range of variation at a rangeof scales: example application. In:
Wiens J, Regan C, Hayward G, Safford H (eds) Historical environmental variation in conservation and natural resource management. Wiley, Hoboken

McKenzie D, Gedalof ZE, Peterson DL, Mote P (2004) Climatic change, wildfire, and conservation. Conserv Biol 18:890-902

Merschel AG, Spies TA, Heyerdahl EK (2014) Mixed-conifer forests of central Oregon: effects of logging and fire exclusion vary with environment. Ecol Appl 24:1670-1688

Meyer MD (2015) Forest fire severity patterns of resource objective wildfires in the southern Sierra Nevada. J For 113:49-56

Millar CI, Stephenson NL, Stephens SL (2007) Climate change and forests of the future: managing in the face of uncertainty. Ecol Appl 17:2145-2151

Millennium Ecosystem Assessment (2005) Ecosystems and human well-being: synthesis. Island Press, Washington

Miller C (2007) Simulation of the consequences of different fire regimes to support wildland fire use decisions. Fire Ecol 3:83-102

Miller C, Davis B (2009) Quantifying the consequences of fire suppression in two California national parks. George Wright Forum 26:76-88

Miller JM, Keen FP (1960) Biology and control of the western pine beetle: a summary of the first fifty years of research. USDA Forest Service Miscellaneous Publication 800, Washington

Miller JD, Safford HD, Crimmins M, Thode AE (2009) Quantitative evidence for increasing forest fire severity in the Sierra Nevada and southern Cascade Mountains, California and Nevada, USA. Ecosystems 12:16-32

Moritz MA, Hessburg PF, Povak NA (2011) Native fire regimes and landscape resilience. In: McKenzie D, Miller CA, Falk DA (eds) The landscape ecology of fire. Springer, New York

Moritz MA, Hurteau MD, Suding KN, D'Antonio CM (2013) Bounded ranges of variation as a framework for future conservation and fire management. Annal NY Acad Sci 1286:92-107

Naficy C, Sala A, Keeling E, Graham J, DeLuca TH (2010) Interactive effects of historical logging and fire exclusion on ponderosa pine forest structure in the northern Rockies. Ecol Appl 20:1851-1864

Neilson RP (1986) High-resolution climatic analysis and southwest biogeography. Science 232:27-34

Neilson RP (1995) A model for predicting continental-scale vegetation distribution and water balance. Ecol Appl 5:362-385

North M (2012) A desired future condition for Sierra Nevada forests. In: M. North (ed.) Managing Sierra Nevada Forests, General Technical Report PSW-GTR-237: 165-175, USDA-FS, Pacific Southwest Research Station, Albany, pp 165-175

North M, Stine P, O'Hara K, Zielinski W, Stephens S (2009) An ecosystem management strategy for Sierran mixed-conifer forests. General Technical Report PSW-GTR-220. Albany: USDA-FS, Pacific Southwest Research Station. p 49

North MP, Collins BM, Stephens SL (2012a) Using fire to increase the scale, benefits and future maintenance of fuels treatments. J For 110:392-401

North M, Boynton RM, Stine PA, Shipley KF, Underwood EC, Roth NE, Viers JH, Quinn JF (2012b) Geographic 
information system landscape analysis using GTR 220 concepts. In: M North (ed) Managing Sierra Nevada Forests, General Technical Report PSW-GTR-237:107-115. USDA-FS, Pacific Southwest Research Station, Albany, p 184

North M, Brough A, Long J, Collins B, Bowden P, Yasuda D, Miller J, Suighara N (2015) Constraints on mechanized treatment significantly limit mechanical fuels reduction extent in the Sierra Nevada. J For 113:40-48

Noss RF, Cooperrider A (1994) Saving nature's legacy: protecting and restoring biodiversity. Island Press, Washington

Noss RF, Franklin JF, Baker WL, SchoennagelT Moyle PB (2006) Managing fire-prone forests in the western United States. Front Ecol Environ 4:481-487

Nyland R (2002) Silviculture: concepts and applications. Waveland Press Inc, New York

Odion DC, Moritz MA, Dellasala DA (2010) Alternative community states maintained by fire in the Klamath Mountains, USA. J Ecol 98:96-105

Odion DC, Hanson CT, Arsenault A, Baker WL, DellaSala DA, Hutto RL, Klenner W, Moritz MA, Sheriff RL, Veblen TT, Williams MA (2014) Examining historical and current mixed-severity fire regimes in ponderosa pine and mixedconifer forests of western North America. PLoS ONE 9(2): 87852

O'Hara K, Latham P, Hessburg PF, Smith BG (1996) Development of a forest stand structural stage classification for the Interior Columbia River Basin. West J Appl For 11:97-102

O'Hara KL, Nagel LM (2013) The stand: revisiting a central concept in forestry. J For 111:335-340

Oliver CD, Larson BC (1996) Forest stand dynamics. McGrawHill, New York

Olson DL, Agee JK (2005) Historical fires in Douglas-fir dominated riparian forests of the southern Cascades, Oregon. Fire Ecol 1:50-74

O'Neill RV (1986) A hierarchical concept of ecosystems. Princeton University Press, Princeton

Parks SA, Holsinger LM, Miller C, Nelson CR (2015) Wildland fire as a self-regulating mechanisms: the role of previous burns and weather in limiting fire progression. Ecol Appl 25(3):768-778

Parsons DJ, DeBenedetti SH (1979) Impact of fire suppression on a mixed-conifer forest. For Ecol Manag 2:21-33

Pearson RG, Dawson TP (2003) Predicting the impacts of climate change on the distribution of species: are bioclimate envelope models useful? Global Ecol Biogeogr 12:361-371

Perera A, Bus LJ, Weber MG (2004) Emulating natural forest landscape disturbances: concepts and applications. Columbia University Press, New York

Perry DA, Hessburg PF, Skinner CN, Spies TA, Stephens SL, Taylor AH, Franklin JF, McComb B, Riegel G (2011) The ecology of mixed severity fire regimes in Washington, Oregon, and Northern California. For Ecol Manag 262:703-717

Peters DPC, Pielke RA, Bestelmeyer BT, Allen CD, MunsonMcGee S, Havstad KM (2004) Cross-scale interactions, nonlinearities, and forecasting catastrophic events. Proceedings of the National Academy of Sciences of the USA, 101:15130-15135
Peterson GD (2002) Contagious disturbance, ecological memory, and the emergence of landscape pattern. Ecosystems $5: 329-338$

Peterson DL, Johnson MC, Agee JK, Jain TB, McKenzie D, Reinhardt ED (2005) Forest structure and fire hazard in dry forests of the Western United States. USDA-FS, General Technical Report PNW-GTR-628, pp 1-30

Peterson DW, Dodson EK, Harrod RJ (2015) Post-fire logging reduces surface woody fuels up to four decades following wildfire. For Ecol Manag 338:84-91

Puettmann KJ, Coates KD, Messier CC (2012) A critique of silviculture: managing for complexity. Island Press, Washington

Raphael MG, Wisdom MJ, Rowland MM, Holthausen RS, Wales BC, Marcot BG, Rich TD (2001) Status and trends of habitats of terrestrial vertebrates in relation to land management in the interior Columbia River Basin. For Ecol Manag 153:63-87

Reed RA, Johnson-Barnard J, Baker WL (1996) Contribution of roads to forest fragmentation in the Rocky Mountains. Conserv Biol 10:1098-1106

Reed DH, O'Grady JJ, Brook BW, Ballou JD, Frankham R (2003) Estimates of minimum viable population sizes for vertebrates and factors influencing those estimates. Biol Conserv 113:23-34

Reeves GH, Bisson PA (2009) Fish and old-growth forests. In: Spies TA, Duncan SL (eds) Old growth in a new world: a Pacific Northwest icon re-examined. Island Press, Washington, pp 70-82

Reeves GH, Benda LE, Burnett KM, Bisson PA, Sedell JR (1995) A disturbance-based ecosystem approach to maintaining and restoring freshwater habitats of evolutionarily significant units of anadromous salmonids in the Pacific Northwest. Am Fish Soc Symp 17:334-349

Reinhardt ED, Keane RE, Calkin DE, Cohen JD (2008) Objectives and considerations for wildland fuel treatment in forested ecosystems of the interior United States. For Ecol Manag 256:1997-2006

Reynolds RT, Meador AJS, Youtz JA, Nicolet T, Matonis MS, Jackson PL, DeLorenzo DG, Graves AD (2013) Restoring composition and structure in southwestern frequent-fire forests: a science-based framework for improving ecosystem resiliency. USDA Forest Service, RMRS-GTR-310

Rieman BE, Hessburg PF, Lee DC, Thurow RF, Sedell JR (2000) Toward an integrated classification of ecosystems: defining opportunities for managing fish and forest health. Environ Manag 25:425-444

Rieman B, Lee D, Burns D, Gresswell R, Young M, Stowell R, Rinne J, Howell P (2003) Status of native fishes in the western United States and issues for fire and fuels management. For Ecol Manag 178:197-211

Rieman BE, Hessburg PF, Luce C, Dare MR (2010) Wildfire and management of forests and native fishes: conflict or opportunity for convergent solutions? Bioscience 60:460-468

Rieman BE, Smith CL, Naiman RJ, Ruggerone GT, Wood CC, Huntly N, Merrill EN, Alldredge JR, Bisson PA, Congleston J, Levings C, Pearcy W, Fausch K, Scarnecchia D, Smouse P (2015) A Comprehensive approach for habitat restoration in the columbia basin. Fisheries 40:124-135

Robbins WG (1999) Landscape and environment: ecological change in the Intermontane Northwest. In: Boyd R (ed) 
Indians, fire, and the land in the pacific northwest. Oregon State University Press, Corvallis, pp 219-237

Sánchez Meador AJ, Moore MM, Bakker JD, Parysow PF (2009) 108 years of change in spatial pattern following selective harvest of a pinus ponderosa stand in northern Arizona, USA. J Veg Sci 20:79-90

Sánchez Meador AJ, Parysow PF, Moore MM (2011) A new method for delineating tree patches and assessing spatial reference conditions ofponderosa pine forests in Northern Arizona. Restor Ecol 19:490-499

Savage M, Swetnam TW (1990) Early 19th century fire decline following sheep pasturing in a Navajo ponderosa pine forest. Ecology 71:2374-2378

Schoennagel T, Veblen TT, Romme W (2004) The interaction of fire, fuels, and climate across Rocky Mountain landscapes. Bioscience 54:661-676

Schultz CA, Jedd T, Beam RD (2012) The collaborative forest landscape restoration program: a history and overview of the first projects. J For 110:381-391

Skinner CN (1995) Change in spatial characteristics of forest openings in the Klamath Mountains of northwestern California, USA. Landscape Ecol 10:219-228

Smith DM, Larson BC, Kelty MJ, Ashton PMS (1997) The practice of silviculture: applied forest ecology. Wiley, New York

Spies TA, Hemstrom MA, Youngblood A, Hummel S (2006) Conserving old-growth forest diversity in disturbanceprone landscapes. Conserv Biol 20:351-362

Spies TA, Lindenmayer DB, Gill AM, Stephens SL, Agee JK (2012) Challenges and a checklist for biodiversity conservation in fire-prone forests: perspectives from the Pacific Northwest of USA and southeastern Australia. Biol Conserv 145:5-14

Spies TA, White EM, Kline JD, Fischer AP, Ager A, Bailey J, Bolte J, Koch J, Platt E, Olsen CS, Jacobs D, Shindler B, Steen-Adams MM, Hammer R (2014) Examining fireprone forest landscapes as coupled human and natural systems. Ecol Soc 19(3):9

Stamps JA, Buechner M, Krishnan VV (1987) The effects of edge permeability and habitat geometry on emigration from patches of habitat. Am Nat 129:533-552

Stephens SL (2004) Fuel loads, snag density, and snag recruitment in an unmanaged Jeffrey pine-mixed-conifer forest in northwestern Mexico. For Ecol Manag 199:103-113

Stephens SL, Fry DL, Franco-Vizcaino E, Collins BM, Moghaddas JJ (2007) Coarse woody debris and canopy cover in an old-growth Jeffrey pine-mixed-conifer forest from the Sierra San Pedro Martir, Mexico. For Ecol Manag 240:87-95

Stephens SL, Fry DL, Franco-Vizcaino E (2008) Wildfire and spatial patterns in forests in northwestern Mexico: the United States wishes it had similar fire problems. Ecol Soc 13(2): 10

Stephens SL, Millar CI, Collins BM (2010) Operational approaches to managing forests of the future in Mediterranean regions within a context of changing climates. Environ Res Lett 5:1-9

Stephens SL, Agee JK, Fulé PZ, North MP, Romme WM, Swetnam TW, Turner MG (2013) Managing forests and fire in changing climates. Science 342:41-42
Stephens SL, Bigelow SW, Burnett RD, Collins BM, Gallagher CV, Keane J, Kelt DA, North MP, Roberts LJ, Stine PA, Van Vuren DH (2014) California spotted owl, songbird, and small mammal responses to landscape-scale fuel treatments. Bioscience 64:893-906

Stephens SL, Lydersen JM, Collins BM, Fry DL, Meyer MD (2015) Historical and current landscape-scale ponderosa pine andmixed-conifer forest structure in the Southern Sierra Nevada. Ecosphere 304:492-504

Stephenson NL (1998) Actual evapotranspiration and deficit: biologically meaningful correlates of vegetation distribution across spatial scales. J Biogeogr 25:855-870

Stine P, Hessburg PF, Spies TA, Kramer M, Fettig CJ, Hansen A, Lehmkuhl J, O'Hara K, Polivka K, Singleton P, Charnley S, Merschel A (2014) The ecology and management of mesic mixed-conifer forests in eastern Oregon and Washington: a synthesis of the relevant biophysical science and implications for future land management. General Technical Report PNW-GTR-897. Portland, p 254

Swanson ME, Franklin JF, Beschta RL, Crisafulli CM, DellaSala DA, Hutto RL, Lindenmayer DB, Swanson FJ (2010) The forgotten stage of forest succession: earlysuccessional ecosystems on forest sites. Front Ecol Environ 9:117-125

Swetnam TW, Allen CD, Betancourt JL (1999) Applied historical ecology: using the past to manage for the future. Ecol Appl 9:1189-1206

Tabor GM, Carlson A, Belote T (2014) Challenges and opportunities for large landscape-scale management in a shifting climate: The importance of nested adaptation responses across geospatial and temporal scales. Rocky Mountain Research Station Paper P-71:205-227. USDA-FS, Fort Collins

Taylor AH (2010) Fire disturbance and forest structure in an oldgrowth Pinus ponderosa forest, southern Cascades, USA. J Veg Sci 21:561-572

Trombulak SC, Frissell CA (2000) Review of ecological effects of roads on terrestrial and aquatic communities. Conserv Biol 14:18-30

Turner M (1989) Landscape ecology: the effect of pattern on process. Ann Rev Ecol Syst 20:171-197

Urban DL, O'Neill RV, Shugart HH Jr (1987) Landscape ecology. Bioscience 37:119-127

USFS (2012) The Okanogan-Wenatchee National Forest Restoration Strategy: Adaptive ecosystem management to restore landscape resiliency. http://www.fs.fed.us/r6/ wenatchee/forest-restoration

USFWS (2012) Endangered and threatened wildlife and plants; designation of revised critical habitat for the northern spotted owl. Final rule; 50 CFR, Part 17, FWS-R1-ES2011-0112; 4500030114, RIN 1018-AX69, Federal Register 77, 233, Tuesday, December 4, 2012, Rules and Regulations; US Gov Printing Office: Washington, pp 71876-2068

Westerling A, Hidalgo H, Cayan D, Swetnam T (2006) Warming and earlier spring increase western US forest wildfire activity. Science 313(5789):940

White R (1991) Its your misfortune and none of my own: a new history of the American West. University of Oklahoma Press, Norman p 644 
Whitlock C, Bartlein PJ (1997) Vegetation and climate change in northwest America during the past $125 \mathrm{kyr}$. Nature 388(6637):57-61

Whitlock C, Shafer SL, Marlon J (2003) The role of climate and vegetation change in shaping past and future fire regimes in the northwestern US and the implications for ecosystem management. For Ecol Manag 178:5-21

Whitlock C, Higuera PE, McWethy DB, Briles CE (2010) Paleoecological perspectives on fire ecology: revisiting the fire-regime concept. Open Ecol J 3:6-23

Wiens J, Milne B (1989) Scaling of 'landscapes' in landscape ecology, or, landscape ecology from a beetle's perspective. Landscape Ecol 3:87-96

Wiens JA, Hayward GD, Safford HD, Giffen C (2012) Historical environmental variation in conservation and natural resource management. Wiley, Hoboken, p 352
Williams MA, Baker WL (2012) Spatially extensive reconstructions show variable-severity fire and heterogeneous structure in historical western United States dry forests. Global Ecol Biogeogr 21:1042-1052

Williams J, Jackson S (2007) Novel climates, no-analog communities, and ecological surprises. Front Ecol Environ 5:475-482

Wondolleck JM, Yaffee SL (2000) Making collaboration work: lessons from innovation in natural resource managment. Island Press, Washington

Wu J, David JL (2002) A spatially explicit hierarchical approach to modeling complex ecological systems: theory and applications. Ecol Model 153:7-26

Wu J, Loucks O (1995) From balance of nature to hierarchical patch dynamics: a paradigm shift in ecology. Quart Rev Biol 70:439-466 